Supporting Information

\title{
Hole-Transporting Materials for Perovskite Solar Cells Employing an Anthradithiophene Core
}

José Santos, ${ }^{* a}$ Joaquín Calbo, ${ }^{\mathrm{b}}$ Rafael Sandoval-Torrientes, ${ }^{\mathrm{a}}$ Inés García-Benito, ${ }^{\mathrm{a}}$ Hiroyuki Kanda, Iwan Zimmermann, ${ }^{c}$ Juan Aragó, ${ }^{b}$ Mohammad Khaja Nazeeruddin, *c Enrique Ortí,*b Nazario

$$
\text { Martín,*a,d }
$$

a Facultad de Ciencias Químicas, Universidad Complutense de Madrid, Madrid, 28040, Spain.

${ }^{\mathrm{b}}$ Instituto de Ciencia Molecular, Universidad de Valencia, Paterna, 46980, Spain.

${ }^{c}$ EPFL VALAIS, Sion, 1951, Switzerland.

d IMDEA-Nanociencia, Ciudad Universitaria de Cantoblanco, Madrid, 28049, Spain.

* Nazario Martín: E-mail: nazmar@ucm.es

* José Santos: E-mail: jose.santos@imdea.org

* Enrique Ortí: E-mail: enrique.orti@uv.es

* Mohammad Khaja Nazeeruddin: E-mail: mdkhaja.nazeeruddin@epfl.ch

Index

1. Experimental Section $S 2$

2. Synthetic Details and Characterization S3

3. Thermal Properties S5

4. Computational Details $\quad \mathrm{S6}$

5. Device Fabrication and Characterization S12

6. ${ }^{1} \mathrm{H}$ NMR, ${ }^{13} \mathrm{C}$ NMR and HRMS spectra $\mathrm{S} 16$

7. References $\quad$ S20 


\section{Experimental Section}

General Methods. Chemicals and reagents were purchased from commercial suppliers and used as received. All solvents were dried according to standard procedures. Airsensitive reactions were carried out under nitrogen atmosphere. The device preparation was done in a glovebox under nitrogen atmosphere. Flash chromatography was performed using silica gel (Fluorochem, Silicagel 60A, 40-63 micron). Analytical thinlayer chromatography (TLC) was performed using aluminum-coated Merck Kieselgel 60 F254 plates. NMR spectra were recorded on a Bruker Advance $300\left({ }^{1} \mathrm{H}: 400 \mathrm{MHz} ;{ }^{13} \mathrm{C}\right.$ : $101 \mathrm{MHz}$ ) spectrometer at $298 \mathrm{~K}$ using partially deuterated solvents as internal standards. Coupling constants $(J)$ are denoted in $\mathrm{Hz}$ and chemical shifts $(\delta)$ in ppm. Multiplicities are denoted as follows: $\mathrm{s}=$ singlet, $\mathrm{d}=$ doublet, $\mathrm{t}=$ triplet, $\mathrm{m}=$ multiplet. UV-vis spectra were recorded in a Varian Cary 50 spectrophotometer. FT-IR spectra were recorded on a Bruker Tensor 27 (ATR device) spectrometer. Photoluminescence (PL) spectra were performed on a Fluorolog-3 HORIBA spectrofluorometer. Mass spectra matrix-assisted laser desorption ionization (coupled to a time-of-flight analyzer) experiments (MALDITOF) were recorded on a MAT 95 thermo spectrometer and a Bruker REFLEX spectrometer respectively. Thermogravimetric analysis (TGA) was performed using a TA Instruments TGAQ500 with a ramp of $10{ }^{\circ} \mathrm{C} \mathrm{min}{ }^{-1}$ under $\mathrm{N}_{2}$ from 100 to $1000{ }^{\circ} \mathrm{C}$. Differential scanning calorimetry (DSC) was run on a Discovery DSC from TA instruments. Three cycles were recorded under nitrogen, heating (until $400{ }^{\circ} \mathrm{C}$ ) and cooling $\left(50^{\circ} \mathrm{C}\right)$ at $20^{\circ} \mathrm{C} \mathrm{min}{ }^{-1}$ of scanning rate. Cyclic voltammetry (CV) experiments were performed in deaerated $0.1 \mathrm{M} \mathrm{Bu}_{4} \mathrm{NPF}_{6}$ dichloromethane (DCM) solutions at a scan rate of $100 \mathrm{mV} \mathrm{s}^{-1}$. Glassy carbon was used as a working electrode and platinum wires as counter and reference electrodes. Before each measurement, solutions were deoxygenated with $\mathrm{N}_{2}$. Ferrocene was added as an internal standard; its oxidation potential in DCM was set at $0.7 \mathrm{~V}$ vs. normal hydrogen electrode (NHE) and materials oxidation potentials were recalculated in reference to NHE. 1,5-Dichloroanthraquinone and mercaptoacetic acid were purchased from commercial suppliers. Compounds $4^{1}$ and $5^{2}$ were obtained according to previously reported procedures. 


\section{Synthetic Details and Characterization.}
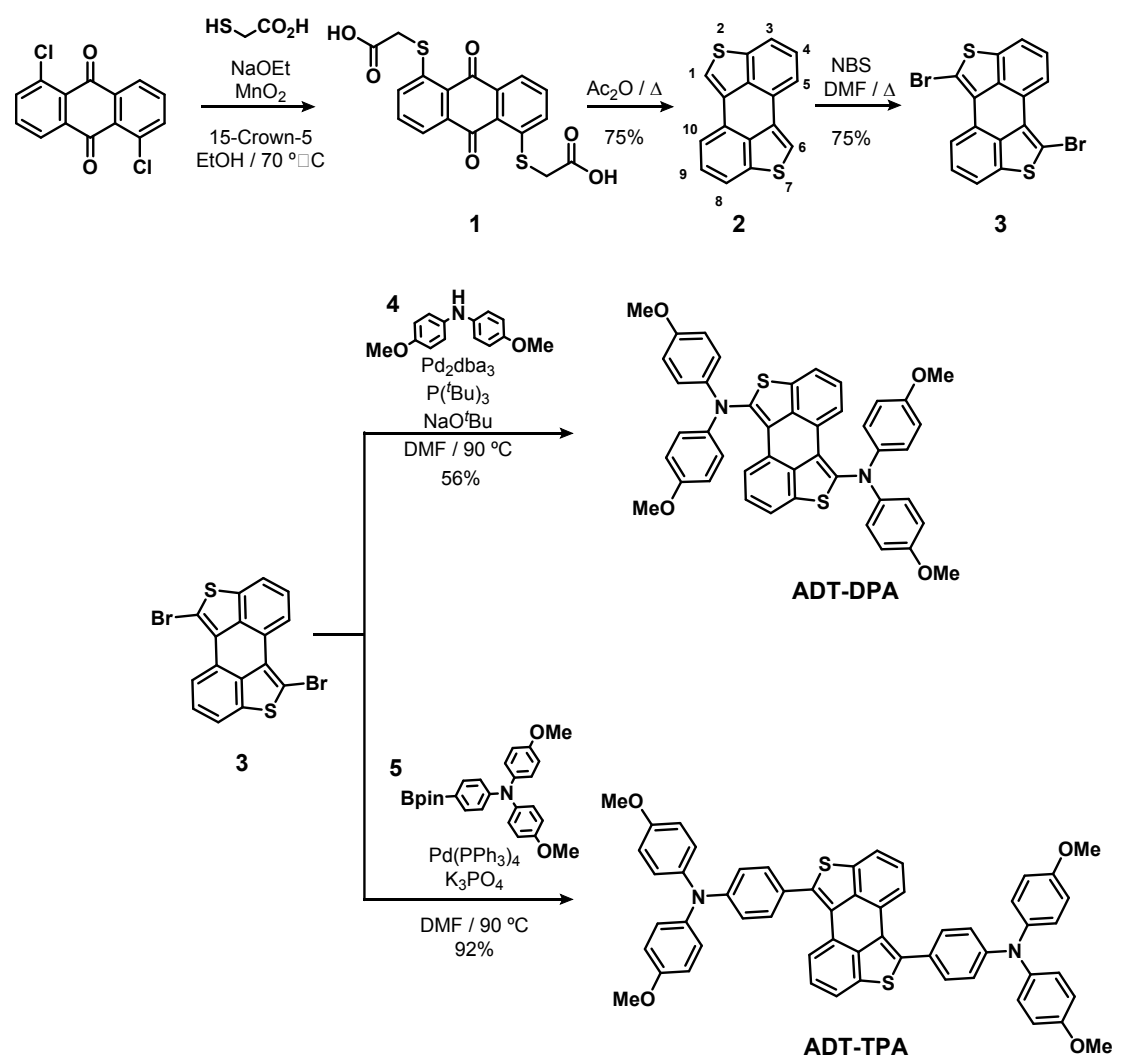

Scheme S1. Synthetic route for the preparation of the new HTMs based on ADT.

\section{Anthra[1,9-bc:5,10-b'c']dithiophene (2)}

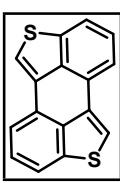

Into a $100 \mathrm{~mL}$ 2-neck round-bottom flask fitted with a condenser, 1,5dichloroanthraquinone $(5.00 \mathrm{~g}, 18.0 \mathrm{mmol})$ was dissolved in a sodium ethoxide ethanol solution $(43 \mathrm{~mL}, 21 \% \mathrm{w} / \mathrm{w})$. Thereafter, mercaptoacetic acid $(3.64 \mathrm{~g}$, $39.6 \mathrm{mmol}$ ) was added in portions at $22{ }^{\circ} \mathrm{C}$, followed by the addition of $\mathrm{MnO}_{2}(0.85 \mathrm{~g}$, $9.85 \mathrm{mmol})$ and 15 -crown-5-ether $(85.0 \mathrm{mg}, 0.40 \mathrm{mmol})$. The resulting mixture was stirred at $70{ }^{\circ} \mathrm{C}$ for $14 \mathrm{~h}$. Upon cooling to room temperature, the mixture was gradually poured into $\mathrm{H}_{2} \mathrm{O}(400 \mathrm{~mL})$, stirred mixture was then acidified to $\mathrm{pH}<3$ with $2 \mathrm{M}$ hydrochloric acid. The formed precipitate was collected by filtration, washed with water, and dried under vacuo to give compound 1 as black solid. The black solid was used in the next step without further purification. Compound 1 (6.89 g, $17.5 \mathrm{mmol})$ was 
suspended in acetic anhydride $(120 \mathrm{~mL})$ and was refluxed for $3 \mathrm{~h}$. Without cooling, the precipitate was collected by filtration and then redissolved in hot $n$-pentane $(250 \mathrm{~mL})$. After removing the solvent under reduced pressure, the reaction crude was purified by flash chromatography (silica gel using hexane/DCM 4:1 as eluent) yielding 2 as a yellow solid (3.62 g, 75\%). ${ }^{1} \mathrm{H}$ NMR (400 MHz, $\left.\mathrm{CDCl}_{3}\right) \delta: 7.70$ (dd, $\left.J=2.9,0.7 \mathrm{~Hz}, 2 \mathrm{H}\right), 7.68$ (dd, $J=3.6,0.7 \mathrm{~Hz}, 2 \mathrm{H}), 7.63(\mathrm{~s}, 2 \mathrm{H}), 7.40-7.35$ (m, 2H) ppm; ${ }^{13} \mathrm{C}$ NMR $(101 \mathrm{MHz}$, $\left.\mathrm{CDCl}_{3}\right) \delta: 140.0,137.5,132.1,128.6,126.1,121.4,118.0,117.3$ ppm; MS (MALDI-TOF) $\mathrm{m} / \mathrm{z}: 264.0$.

\section{1,6-Dibromoanthra[1,9-bc:5,10-b'c']dithiophene (3)}

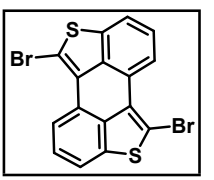

Into a solution of $2(0.28 \mathrm{~g}, 1.08 \mathrm{mmol})$ in dry DMF $(35 \mathrm{~mL})$, a solution of $\mathrm{N}$-bromosuccinimide $(0.67 \mathrm{~g}, 3.77 \mathrm{mmol})$ in DMF $(6 \mathrm{~mL})$ was dropwise added. The resulting mixture was stirred at $110^{\circ} \mathrm{C}$ until totally dissolved.

Thereafter, the mixture was cooled down to $80^{\circ} \mathrm{C}$ during $1 \mathrm{~h}$. The formed precipitate was collected by filtration, washed with acetone, and dried under vacuum to give rise to 3 as a pale yellow solid (0.32 g, 75\%). ${ }^{1} \mathrm{H}$ NMR (400 MHz, DMSO-d $\left.{ }^{6}\right) \delta: 8.66(\mathrm{~d}, \mathrm{~J}=7.7 \mathrm{~Hz}$, $2 \mathrm{H}), 7.97(\mathrm{~d}, J=7.9 \mathrm{~Hz}, 2 \mathrm{H}), 7.59(\mathrm{t}, J=8.0 \mathrm{~Hz}, 2 \mathrm{H}) \mathrm{ppm} ;{ }^{13} \mathrm{C}$ NMR could not be recorded due to compound's lack of solubility; HRMS (MALDI-TOF): $\mathrm{m} / \mathrm{z}$ calculated for $\mathrm{C}_{16} \mathrm{H}_{6} \mathrm{Br}_{2} \mathrm{~S}_{2}$ : 419.8, found: 419.9 .

\section{ADT-DPA}

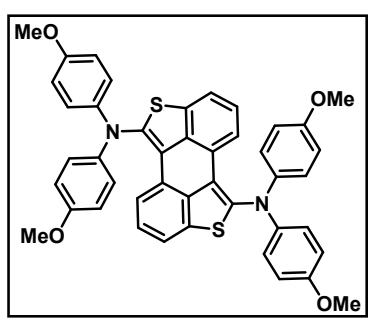

Into a $100 \mathrm{~mL}$ 2-neck round-bottom flask fitted with a condenser, 3 (120 mg, $0.30 \mathrm{mmol}$ ), bis(4-methoxyphenyl)amine (150 mg, $0.67 \mathrm{mmol}$ ), and $\mathrm{Pd}_{2} \mathrm{dba}_{3}(13.0 \mathrm{mg}, 0.01 \mathrm{mmol}$ ) were dissolved in dry DMF $(25 \mathrm{~mL})$ under nitrogen atmosphere. The mixture was degassed for $30 \mathrm{~min}$. tert-BuONa (84.0 $\mathrm{mg}, 0.88 \mathrm{mmol})$ was then added in one portion and the resulting mixture stirred at $110{ }^{\circ} \mathrm{C}$ for $5 \mathrm{~h}$. Upon cooling to room temperature, the solvent was removed under reduced pressure and the reaction crude purified by flash chromatography (silica gel, DCM) to afford ADT-DPA as a yellow solid (120 mg, 56\%). ${ }^{1} \mathrm{H}$ NMR (400 MHz, THF-d $\left.{ }^{8}\right) \delta .7 .82$ (d, J = 7.8 Hz, 2H), 7.44 (d, J $=8.0 \mathrm{~Hz}, 2 \mathrm{H}), 7.14-7.06(\mathrm{~m}, 10 \mathrm{H}), 6.86-6.77(\mathrm{~m}, 8 \mathrm{H}), 3.72(\mathrm{~s}, 12 \mathrm{H}) \mathrm{ppm} ;{ }^{13} \mathrm{C}$ NMR $(101$ MHz, THF-d $\left.{ }^{8}\right) \delta: 157.3,144.8,141.4,137.8,137.6,128.5,126.7,124.3,124.0,121.5$, 121.1, 115.5, 55.7 ppm; FTIR (neat): 3849, 3726, 3680, 3650, 3620, 2950, 2836, 1741, 1645 1546, 1504, 1462, 1406, 1358, 1242, 1179, 1035, 825, $778 \mathrm{~cm}^{-1}$; HRMS (MALDITOF): $\mathrm{m} / \mathrm{z}$ calculated for $\mathrm{C}_{44} \mathrm{H}_{34} \mathrm{~N}_{2} \mathrm{O}_{4} \mathrm{~S}_{2}: 718.1955$, found: 718.1923 .

\section{ADT-TPA}




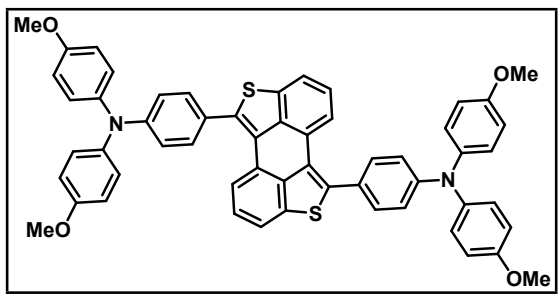

Into a $100 \mathrm{~mL}$ 2-neck round-bottom flask fitted with a condenser, 3 (200 mg, $0.47 \mathrm{mmol})$, 4-(4,4,5,5tetramethyl-1,3,2-dioxaborolan-2-yl)-N,N-bis(4methoxyphenyl)aniline (510 $\mathrm{mg}, 1.20 \mathrm{mmol})$, and $\mathrm{Pd}\left(\mathrm{PPh}_{3}\right)_{4}(54.0 \mathrm{mg}, 0.05 \mathrm{mmol})$ were dissolved in dry

DMF (25 mL) under nitrogen atmosphere. After degassing the mixture for $30 \mathrm{~min}, \mathrm{~K}_{3} \mathrm{PO}_{4}$ $(1.20 \mathrm{~g}, 5.68 \mathrm{mmol})$ was added in one portion and the reaction stirred at $100{ }^{\circ} \mathrm{C}$ for $2 \mathrm{~h}$. Upon cooling to room temperature, the reaction was quenched with $\mathrm{H}_{2} \mathrm{O}(20 \mathrm{~mL})$. The formed precipitate was filtered off and sequentially washed with $\mathrm{H}_{2} \mathrm{O}$ and $\mathrm{MeOH}$. Thereafter, the precipitate was redissolved in DCM $(50 \mathrm{~mL})$, the solvent removed under reduced pressure and the reaction crude purified by flash chromatography (silica gel, $\mathrm{DCM})$ to give a pale orange solid (380 mg, 92\%). ${ }^{1} \mathrm{H}$ NMR $\left(400 \mathrm{MHz}\right.$, THF-d $\left.{ }^{8}\right) \delta: 7.58-$ $7.53(\mathrm{~m}, 4 \mathrm{H}), 7.43-7.39(\mathrm{~m}, 4 \mathrm{H}), 7.18-7.14(\mathrm{~m}, 8 \mathrm{H}), 7.12-7.06(\mathrm{~m}, 2 \mathrm{H}), 7.01-6.96(\mathrm{~m}$, $4 \mathrm{H}), 6.93-6.88(\mathrm{~m}, 8 \mathrm{H}), 3.77$ (s, 12H) ppm; ${ }^{13} \mathrm{C}$ NMR (101 MHz, THF-d $\left.{ }^{8}\right) \delta: 158.0,150.8$, 141.3, 140.1, 139.8, 138.4, 131.2, 130.4, 128.4, 127.2, 126.7, 126.1, 121.1, 120.1, 115.8, 55.8 ppm; FTIR (KBr): 3008, 2945, 2832, 1605, 1546, 1499, 1464, 1405 1319, 1288 , 1234, 1173, 1100, 1028, 914, 879, 823, 767, 721, 677, 649,601, $573 \mathrm{~cm}^{-1}$; HRMS (MALDI-TOF): $\mathrm{m} / \mathrm{z}$ calculated for $\mathrm{C}_{56} \mathrm{H}_{42} \mathrm{~N}_{2} \mathrm{O}_{4} \mathrm{~S}_{2}: 870.2581$, found: 870.2584.

\section{Thermal Properties}
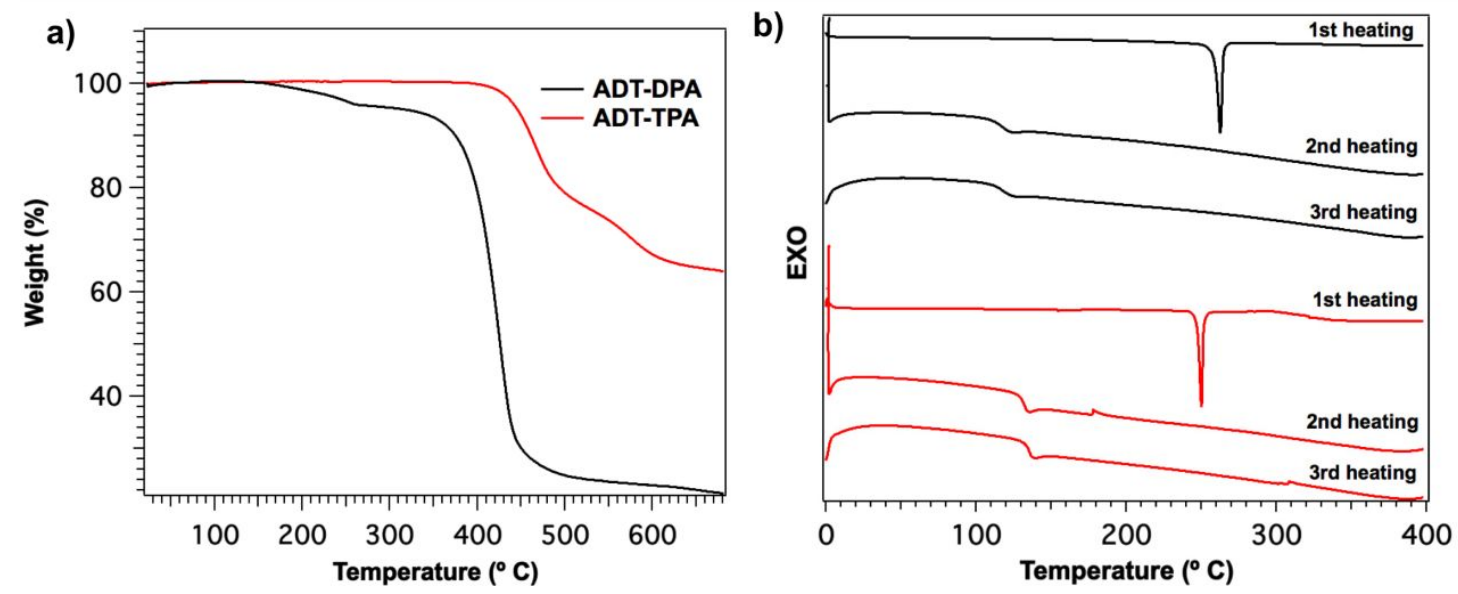

Figure S1. a) Thermogravimetric analysis of the HTMs under nitrogen at a heating rate of $10{ }^{\circ} \mathrm{C}$ $\mathrm{min}^{-1}$. b) Differential scanning calorimetry of ADT-TPA (red) and ADT-DPA (black) under nitrogen at a heating rate of $20^{\circ} \mathrm{C} \mathrm{min}^{-1}\left(1^{\text {st }}, 2^{\text {nd }}\right.$, and $3^{\text {rd }}$ cycles $)$. 


\section{Computational Details}

Quantum-chemical calculations were carried out with the Gaussian 16 (revision A.03) software package. ${ }^{3}$ All the calculations were performed within the density functional theory (DFT) framework using the B3LYP functional ${ }^{4}$ and the $6-31 \mathrm{G}^{* *}$ basis set. ${ }^{5}$ Solvent effects were considered within the self-consistent reaction field (SCRF) theory by using the polarized continuum model (PCM) approach. ${ }^{6} C_{2}$-symmetry constraints were imposed during the optimization of the ADT-DPA and ADT-TPA HTMs, whereas $C_{2 h}$ constraints were used to calculate the isolated ADT core. The DPA and TPA substituent groups as well as the spiro-OMeTAD reference molecule were also optimized under $C_{2}$ symmetry. Vertical electronic transition energies to the lowest-energy singlet excited states of ADT-DPA and ADT-TPA were computed by using the time-dependent DFT (TDDFT) approach. ${ }^{7}$ The lowest 80 singlet excited states were calculated at the $B 3 L Y P / 6-31 G^{* *}$ level using the ground-state optimized geometries. Geometry optimizations in gas phase of the radical cations of ADT-DPA and ADT-TPA, the ADT core, the DPA and TPA terminal groups, and spiro-OMeTAD were also performed to evaluate the reorganization energy $(\lambda)$. The procedure used to evaluate $\lambda$ is explained below. To investigate the oxidation processes, the ionization energies upon to the dication species were estimated in solution. Radical cations were treated as open-shell systems and computed within the spin-unrestricted DFT approximation at the UB3LYP/6$31 \mathrm{G}^{* *}$ level in the presence of $\mathrm{CH}_{2} \mathrm{Cl}_{2}$. Additionally, dication species were also computed in $\mathrm{CH}_{2} \mathrm{Cl}_{2}$. Molecular orbitals were plotted using the Chemcraft 1.6 software with isovalue contours of \pm 0.03 a.u. ${ }^{8}$

Molecular structures. Figure S2 displays the optimized structures of the two-limbed HTMs. Figure S3 shows the B3LYP/6-31G**-optimized values calculated for selected bond lengths of the ADT core and the ADT-DPA and ADT-TPA HTMs. 
a)
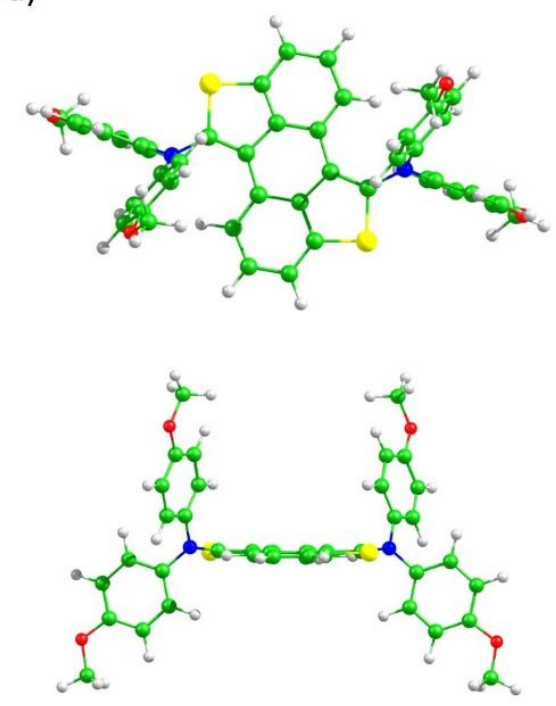

b)
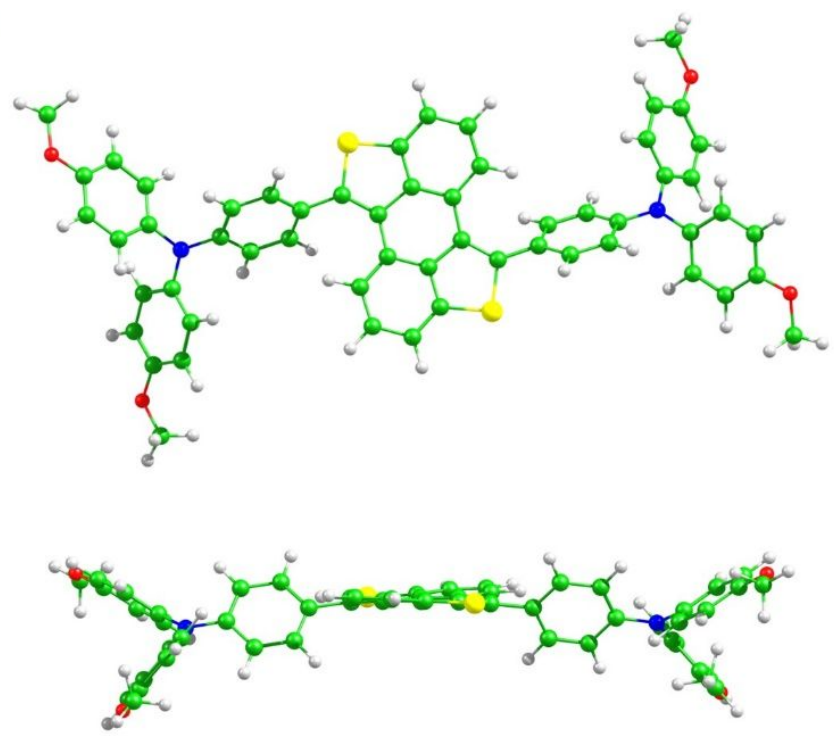

Figure S2. Top and side views of the B3LYP/6-31G**-optimized geometries calculated in $\mathrm{CH}_{2} \mathrm{Cl}_{2}$ solution for the ADT-DPA (a) and ADT-TPA (b) HTMs.

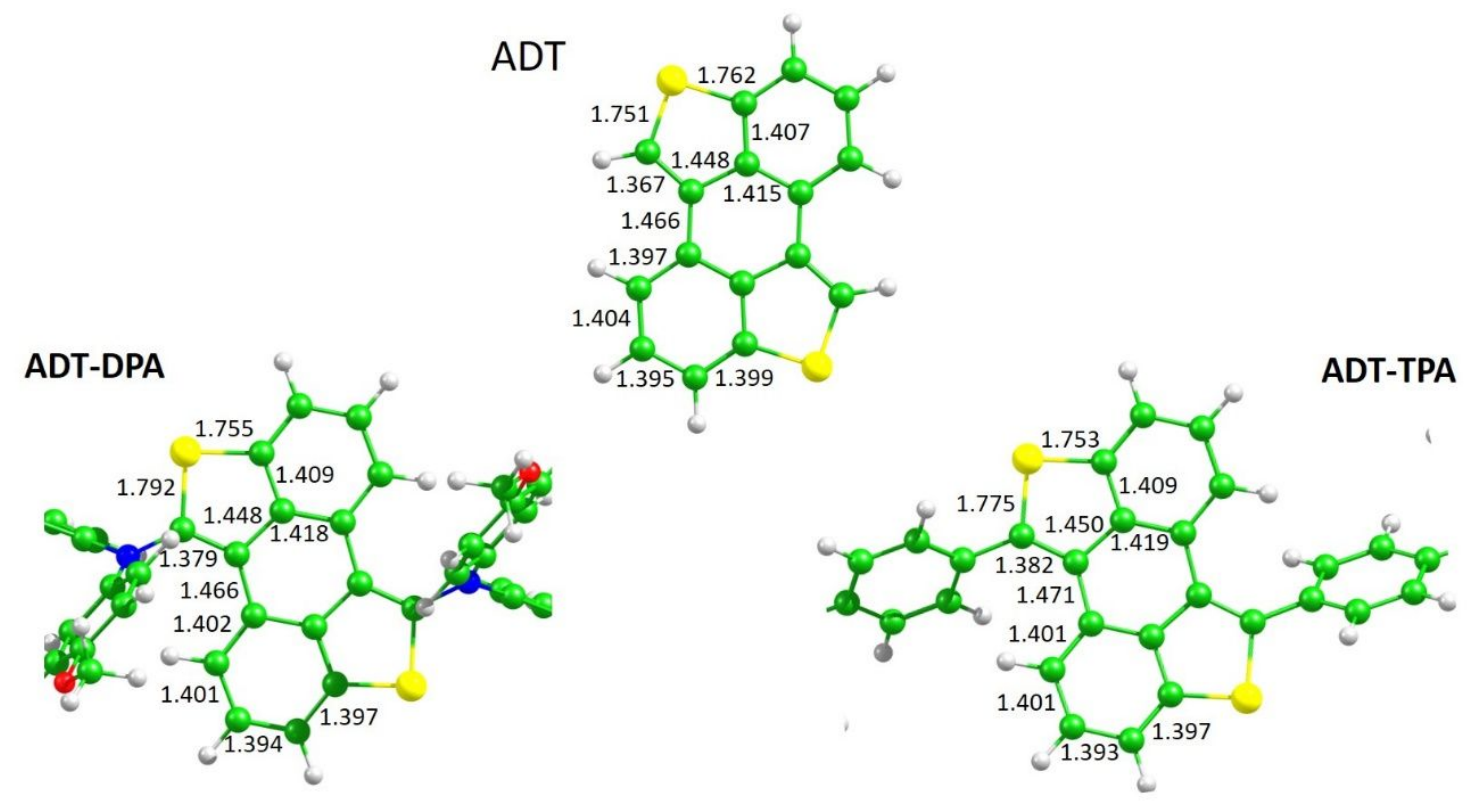

Figure S3. Optimized bond lengths (in $\AA$ ) calculated at the B3LYP/6-31G** level, in $\mathrm{CH}_{2} \mathrm{Cl}_{2}$ solution, for the ADT core and for the ADT-DPA and ADT-TPA compounds. For the latter, the terminal DPA and TPA groups have been partially omitted and only the bond lengths calculated for the ADT core are quoted. 
Oxidized species. B3LYP/6-31G** calculations in $\mathrm{CH}_{2} \mathrm{Cl}_{2}$ were used to investigate the molecular structure and charge distribution of the two-branched ADT-DPA and ADTTPA HTMs in different oxidation states, monocation and dication. The radical cation species was computed as a doublet open-shell species. The dication was calculated both as a singlet closed-shell species, in which both electrons are extracted from the same orbital, and as a triplet open-shell species, in which the electrons are extracted from different orbitals. The singlet state was found to be more stable than the triplet state by $0.28 \mathrm{eV}$ for ADT-DPA whereas the triplet is the most stable by $0.13 \mathrm{eV}$ compared to the singlet for ADT-TPA. Table S1 gathers the Mulliken atomic charges computed for the central ADT cores and the peripheral DPA and TPA groups of the different oxidized species of ADT-DPA and ADT-TPA in their most stable electronic states.

Table S1. Mulliken atomic charges (in e) computed for the central ADT core and the DPA and TPA peripheral units of ADT-DPA and ADT-TPA in different oxidized states.

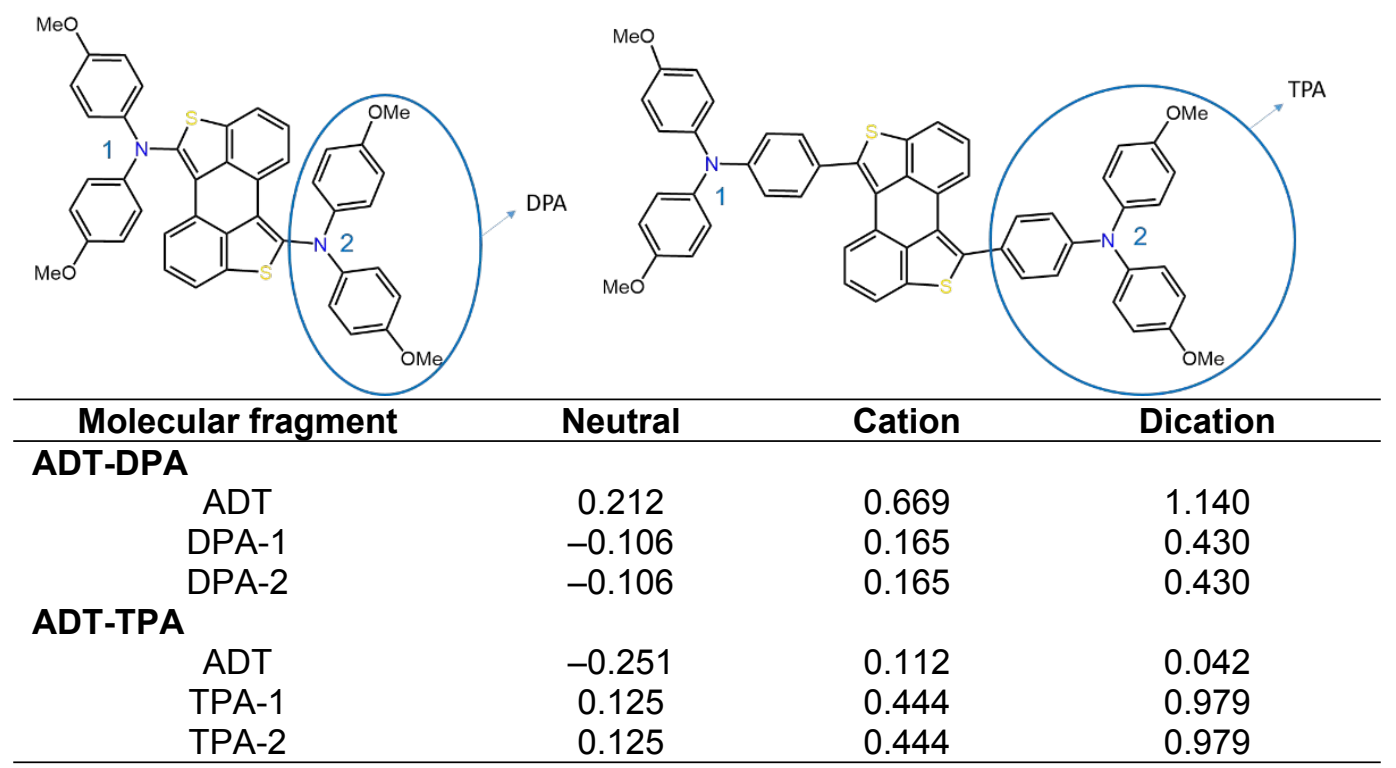


Figure S4 represents the potential energy surfaces for the neutral and cation states of two molecules (labelled as 1 and 2) involved in an intermolecular charge transfer process. The intramolecular reorganization energy $(\lambda)$ consists of two terms related to the geometry relaxation energies of one molecule going from the fully relaxed ground state of the neutral species to the cation state (Figure S4, left) and a neighbouring molecule evolving in the opposite way (Figure S4, right),

$$
\begin{aligned}
& \lambda=\lambda_{1}+\lambda_{2} \\
& \lambda_{1}=E(M 1)-E\left(M 1^{+}\right) \\
& \lambda_{2}=E\left(M 2^{+}\right)-E(M 2)
\end{aligned}
$$

Here, $E(M 1)$ and $E\left(\mathrm{M}^{+}\right)$for molecule 1 are the energies of the positively charged molecule (the cation) at the equilibrium geometry of the neutral molecule and the relaxed cation, respectively, and $E\left(\mathrm{M}_{2}{ }^{+}\right)$and $\mathrm{E}(\mathrm{M} 2)$ for molecule 2 are, accordingly, the energies of the neutral molecule at the equilibrium geometry of the cation and the neutral molecule, respectively.

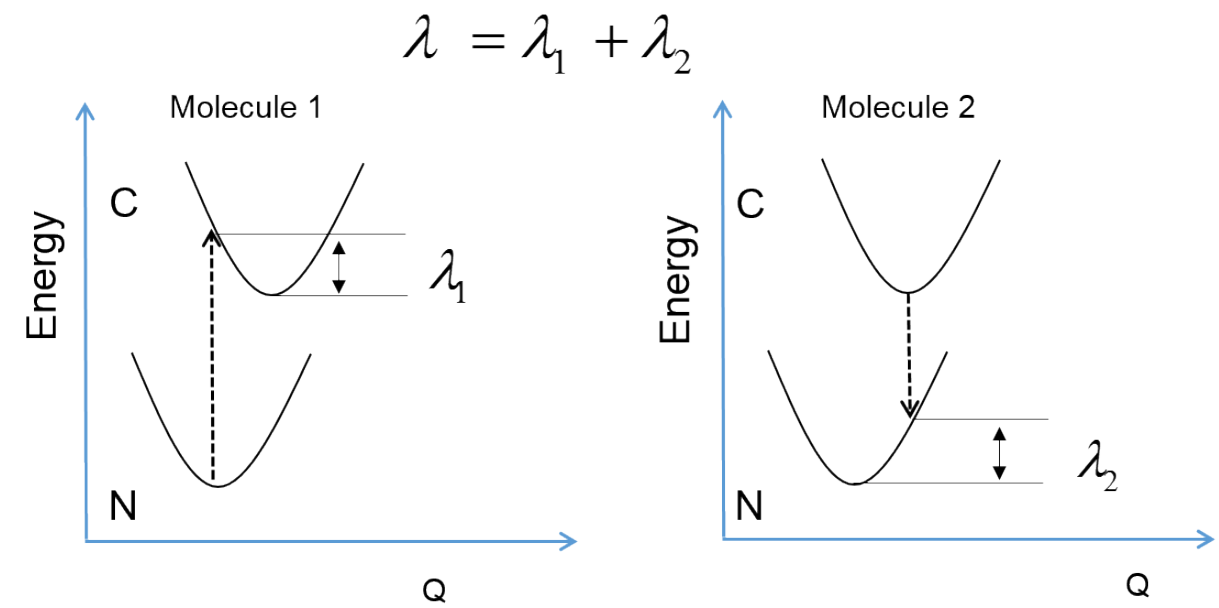

Figure S4. Scheme of the potential energy surfaces of the neutral state $(\mathrm{N})$ and the cation state (C) for two molecules (1 and 2) involved in a charge (hole) transfer process. $\lambda_{1}$ and $\lambda_{2}$ are the two contributions to the total intramolecular reorganization energy $(\lambda)$. 
Electronic spectra. Figure S5 displays the theoretical simulation of the absorption spectra calculated for ADT-DPA and ADT-TPA from the electronic transitions computed at the TDDFT B3LYP/6-31G** level in $\mathrm{CH}_{2} \mathrm{Cl}_{2}$ solution. Table $\mathrm{S} 2$ gathers the vertical excitation energies $(E)$, the oscillator strengths $(f)$, and the electronic descriptions in terms of one-electron molecular orbital excitations calculated for the most relevant $\mathrm{S}_{0} \rightarrow$ $\mathrm{S}_{\mathrm{n}}$ electronic transitions of ADT-DPA and ADT-TPA in $\mathrm{CH}_{2} \mathrm{Cl}_{2}$. Figure $\mathrm{S} 6$ depicts the topology and energy of the frontier molecular orbitals participating in the $S_{0} \rightarrow S_{n}$ transitions quoted in Table S2.
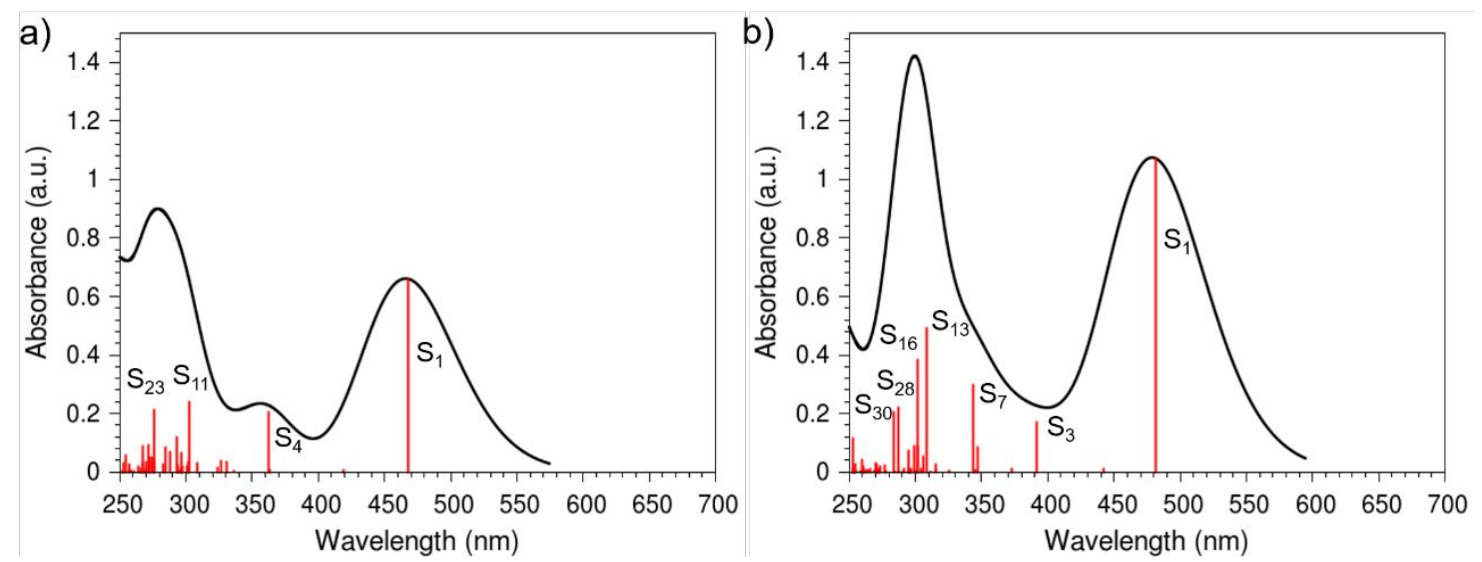

Figure S5. Stick and convoluted absorption spectra computed for ADT-DPA (a) and ADT-TPA (b) at the TDDFT B3LYP/6-31G ${ }^{* *}$ level in $\mathrm{CH}_{2} \mathrm{Cl}_{2}$. The TDDFT stick spectra were convoluted with Gaussian functions of full-width at half maximum (FWHM) of $0.20 \mathrm{eV}$.

Table S2. Lowest-energy singlet excited states calculated at the TDDFT B3LYP/6-31G** level for ADT-DPA and ADT-TPA in $\mathrm{CH}_{2} \mathrm{Cl}_{2}$ solution. Vertical excitation energies $(E)$, oscillator strengths $(f)$ and dominant monoexcitations with contributions (within parentheses) greater than $10 \%$.

\begin{tabular}{llll}
\hline State & $E(\mathrm{eV} / \mathrm{nm})$ & $f$ & Description $^{a}$ \\
\hline ADT-DPA & & & \\
$\mathrm{S}_{1}$ & $2.65 / 468$ & 0.659 & $\mathrm{H} \rightarrow \mathrm{L}(96)$ \\
$\mathrm{S}_{4}$ & $3.42 / 362$ & 0.205 & $\mathrm{H}-2 \rightarrow \mathrm{L}(93)$ \\
& & & \\
ADT-TPA & & & \\
$\mathrm{S}_{1}$ & $2.58 / 481$ & 1.068 & $\mathrm{H} \rightarrow \mathrm{L}(98)$ \\
$\mathrm{S}_{3}$ & $3.17 / 392$ & 0.168 & $\mathrm{H}-2 \rightarrow \mathrm{L}(97)$ \\
$\mathrm{S}_{7}$ & $3.61 / 343$ & 0.299 & $\mathrm{H}-1 \rightarrow \mathrm{L}+1(59)$ \\
& & & $\mathrm{H}-1 \rightarrow \mathrm{L}+3(11)$ \\
& & & $\mathrm{H} \rightarrow \mathrm{L}+2(26)$ \\
\hline
\end{tabular}

${ }^{a} \mathrm{H}$ and $\mathrm{L}$ denotes $\mathrm{HOMO}$ and LUMO, respectively. 
a)

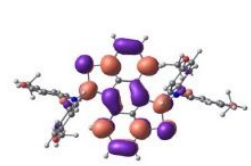

LUMO+1 (-0.75 eV)
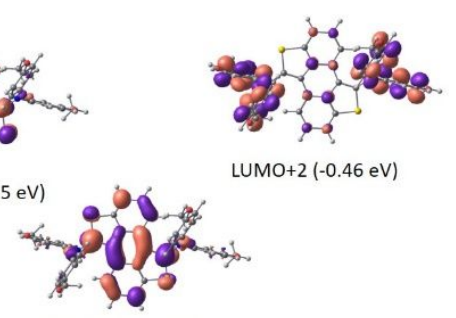

LUMO (-1.61 eV)
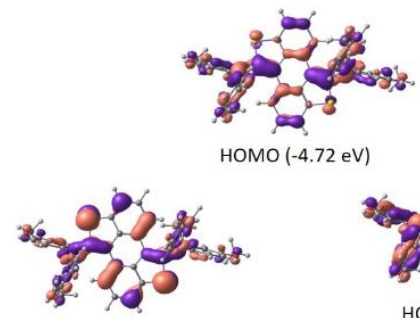

HOMO-2 $(-5.48 \mathrm{eV})$

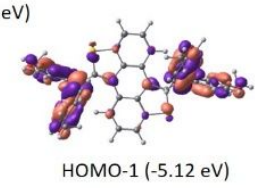

b)
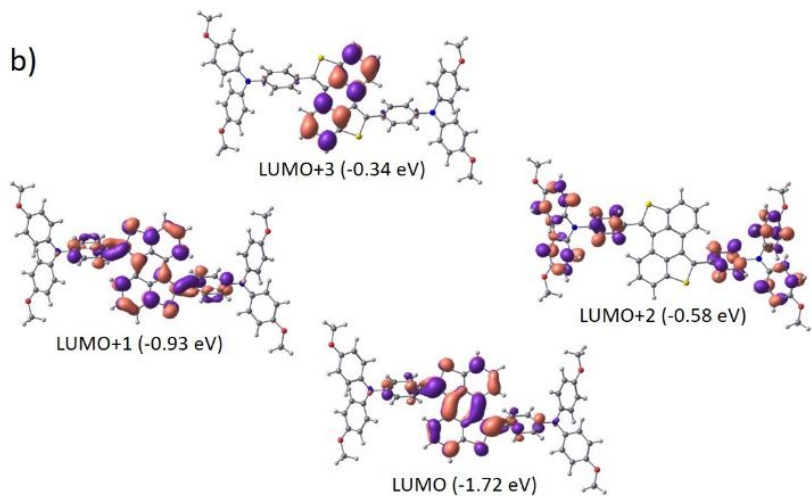

LUMO $(-1.72 \mathrm{eV})$
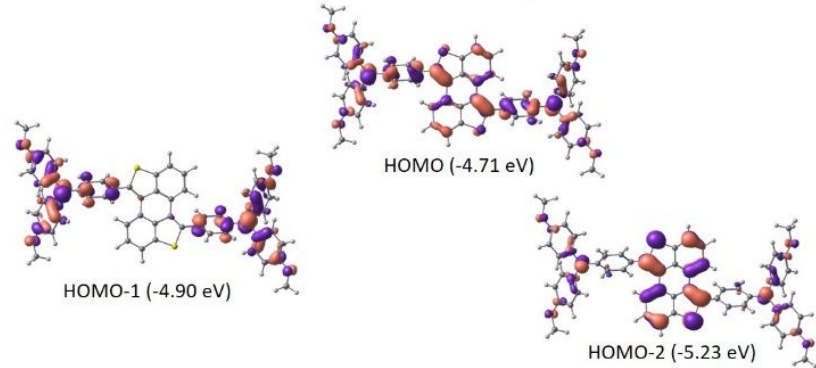

Figure S6. Isovalue contours ( \pm 0.03 a.u.) and energies calculated at the B3LYP/6-31G** level in $\mathrm{CH}_{2} \mathrm{Cl}_{2}$ for selected molecular orbitals of ADT-DPA (a) and ADT-TPA (b). 


\section{Device fabrication and characterization}

\subsection{Device preparation}

Devices were fabricated onto fluorine-doped tin oxide (FTO) coated glass substrates (NSG-10). The substrates were cut and cleaned by sequential treatment with a $2 \%$ aqueous Helmanex solution and isopropanol in an ultrasonic bath for 20 and 10 minutes, respectively. The titania blocking layer $\left(\mathrm{c}-\mathrm{TiO}_{2}\right)$ was applied by spray pyrolysis from a precursor solution of $0.2 \mathrm{~mL}$ titanium diisopropoxide bis(acetylacetonate) in $5 \mathrm{~mL}$ ethanol at $450{ }^{\circ} \mathrm{C}$ in ambient atmosphere. A $150 \mathrm{~nm}$-thick mesoporous $\mathrm{TiO}_{2}$ layer $\left(\mathrm{m}-\mathrm{TiO}_{2}\right)$ was obtained by spin coating a titanium dioxide paste (30 $\mathrm{nm}$ particle size) from GreatCell Solar diluted in ethanol. The substrates were then sintered at $450{ }^{\circ} \mathrm{C}$ for $30 \mathrm{~min}$. For the

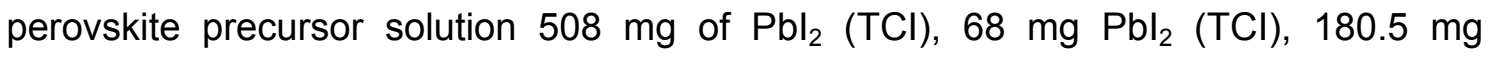
formamidinium iodide (GreatCell Solar) and $20.7 \mathrm{mg}$ methylammonium bromide (GreatCell Solar) were dissolved in a 1:4 mixture of DMSO:DMF. The perovskite solution was spun at $5000 \mathrm{rpm}$ for $30 \mathrm{~s}$ using a ramp of $2000 \mathrm{rpm} \mathrm{s}^{-1} .15 \mathrm{~s}$ prior to the end of the spin-coating sequence $100 \mu \mathrm{L}$ of chlorobenzene were poured onto the spinning substrate. Afterwards, the substrates were transferred onto a hot plate and annealed at $100{ }^{\circ} \mathrm{C}$ for $50 \mathrm{~min}$. The hole-transporting materials were dynamically spin-coated from solutions at $4000 \mathrm{rpm}$ for $25 \mathrm{~s}$. The hole transporters were dissolved in chlorobenzene with concentrations of $0.06 \mathrm{M}$ for spiro-OMeTAD and $0.03 \mathrm{M}$ for ADT-DPA and ADTTPA. Tert-butylpyridine (Tbp), lithium bis(trifluoromethanesulfonyl)imide (Li-TFSI) and tris(2-(1H-pyrazol-1-yl)-4-tert-butylpyridine)cobalt(III) tri[bis(trifluoromethane)sulfonimide (FK $209 \mathrm{Co}(\mathrm{III})$-TFSI) were added as additives. Equimolar amounts of additives were added for all hole transporters: $330 \mathrm{~mol} \%$ Tbp, $50 \mathrm{~mol} \%$ Li-TFSI from a $1.8 \mathrm{M}$ stock solution in acetonitrile and 6 mol\% FK209 from a $0.25 \mathrm{M}$ stock solution in acetonitrile. All HTM solutions were filtered using a syringe filter with a pore size of $0.22 \mu \mathrm{m}$ prior to use. For the top electrodes $70 \mathrm{~nm}$ of gold was thermally evaporated under high vacuum.

\subsection{Solar cell characterization}

SEM images were recorded using a FEI Teneo microscope. Conductivity measurements were performed on substrates having interdigitating gold electrodes with a channel length of $2.5 \mu \mathrm{m}$. HTMs were spin-coated onto the substrates using the same conditions and concentrations as for the devices. 6 mol\% FK209 was used as dopant. Current density-voltage characteristics were measured in air under AM 1.5 simulated sunlight (100 $\mathrm{mW} \mathrm{cm}^{-2}$ ) with a potentiostat (Keithley). The light intensity was measured for calibration with an NREL certified KG5 filtered Si reference diode. The solar cells were masked with a metal aperture of $0.16 \mathrm{~cm}^{2}$ to define the active area. The current density- 
voltage curves were recorded scanning at $10 \mathrm{mV} \mathrm{s}^{-1}$. MPPT study was performed under 1 sun illumination with nitrogen atmosphere with $\mathrm{RHO} \%$ at $25{ }^{\circ} \mathrm{C}$.

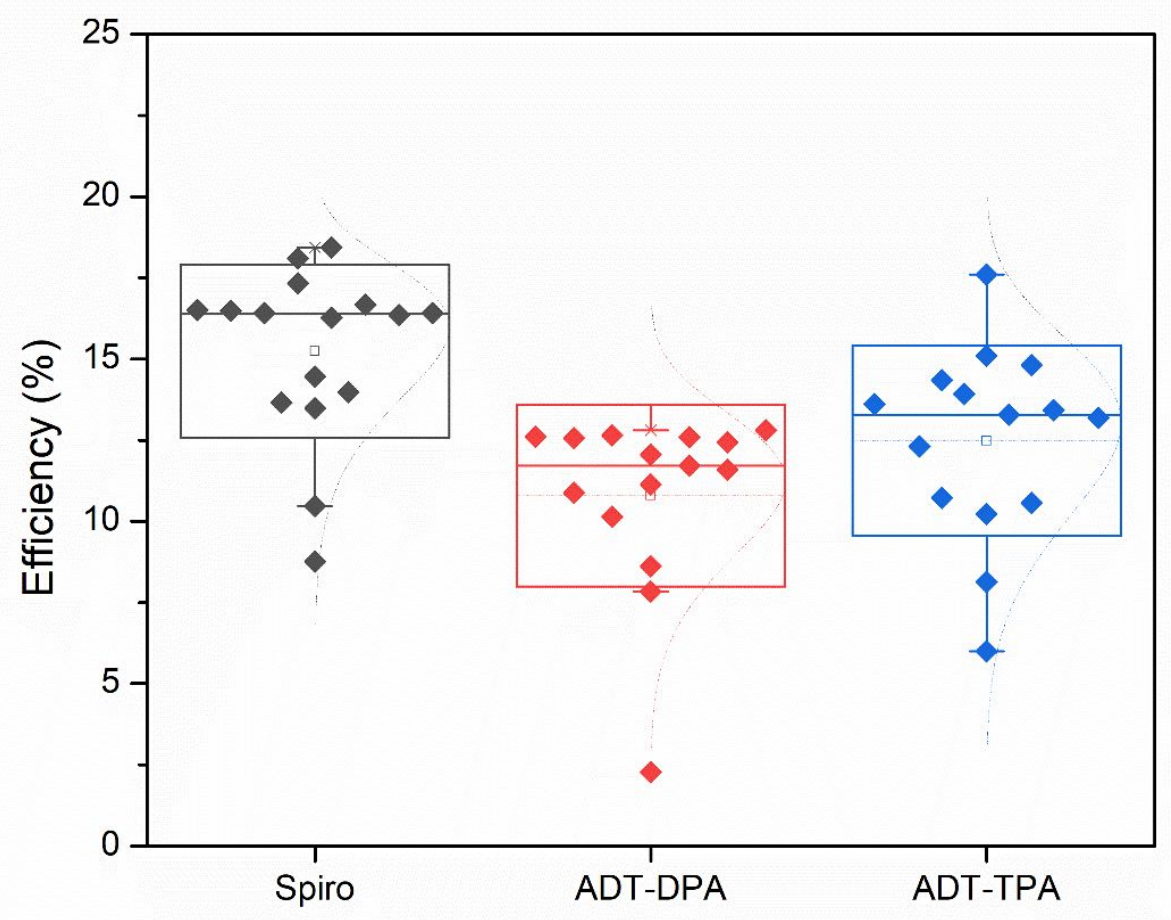

Figure S7. Performance statistics (averages, standard deviations) for Spiro-OMeTAD, ADT-TPA and ADT-DPA-based devices.

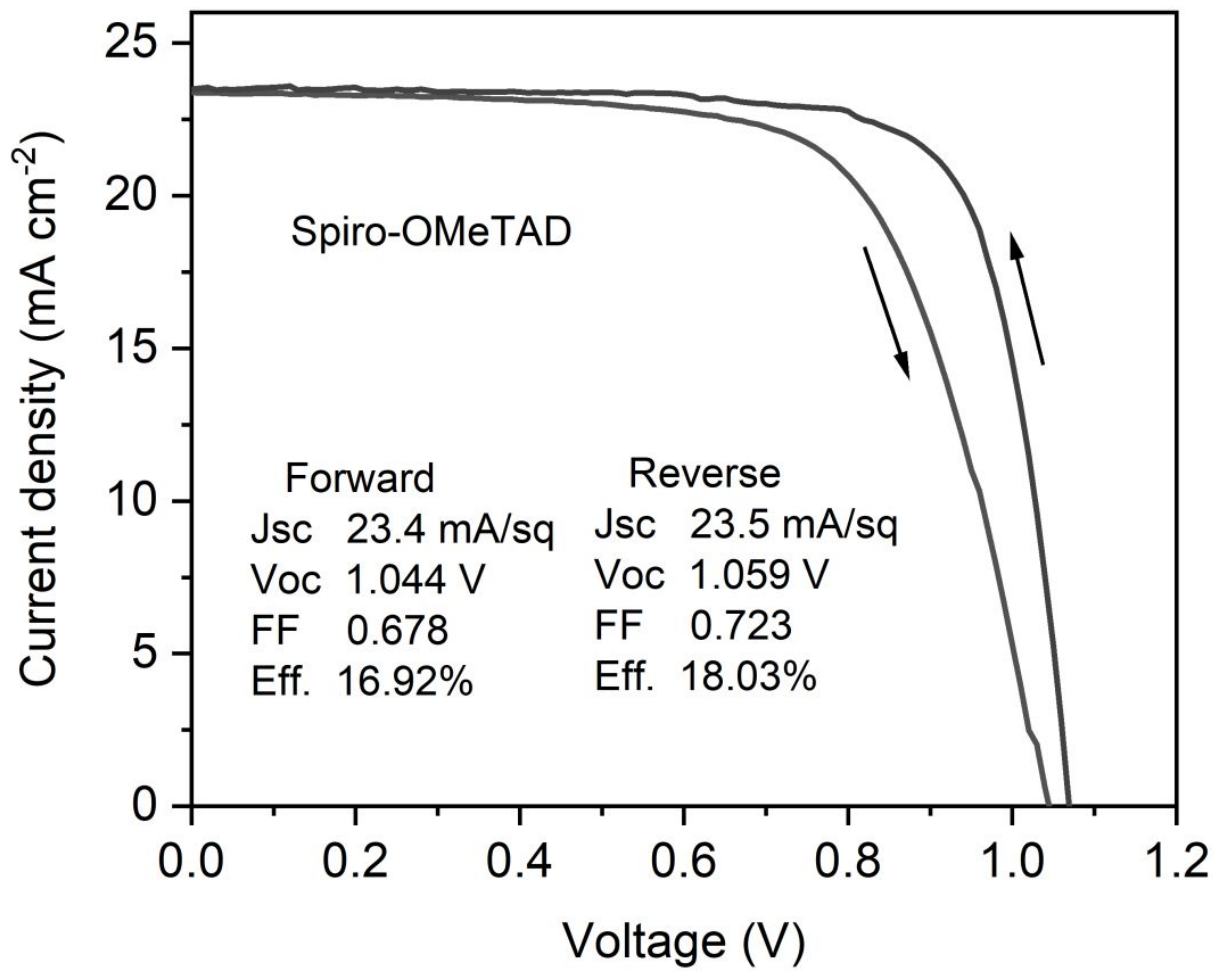

Figure S8. J/V curve of the reference cell fabricated with spiro-OMeTAD as HTM. 


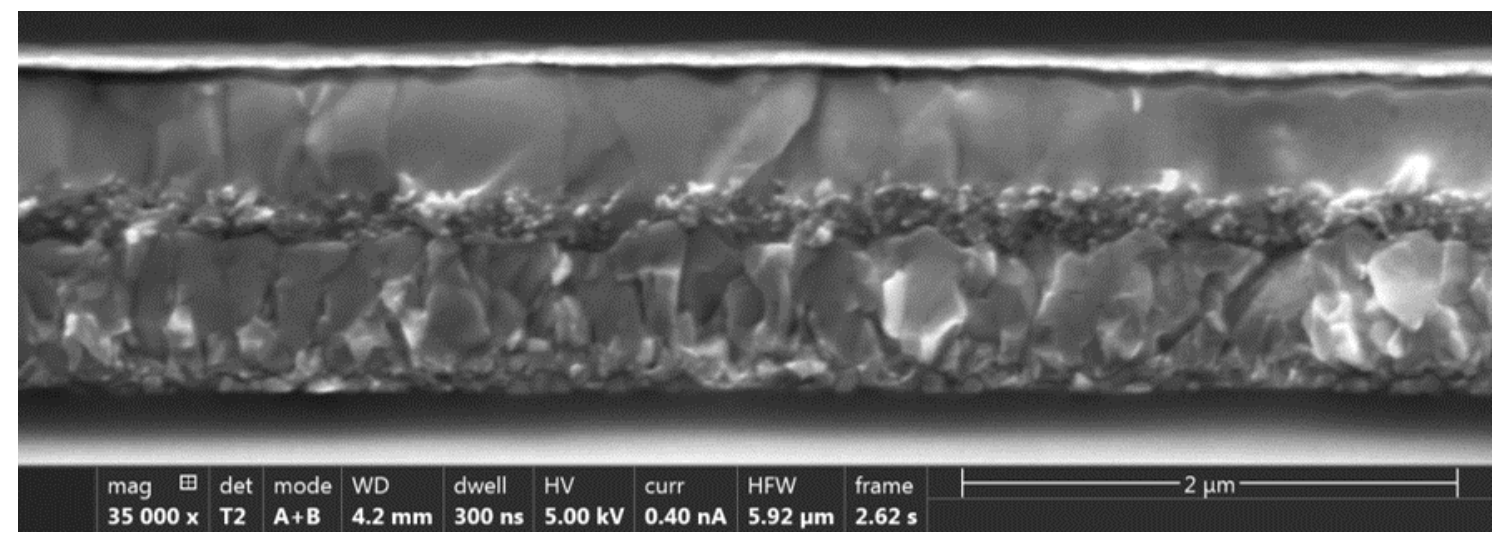

Figure S9. Cross-sectional image of a device fabricated with ADT-DPA as HTM.

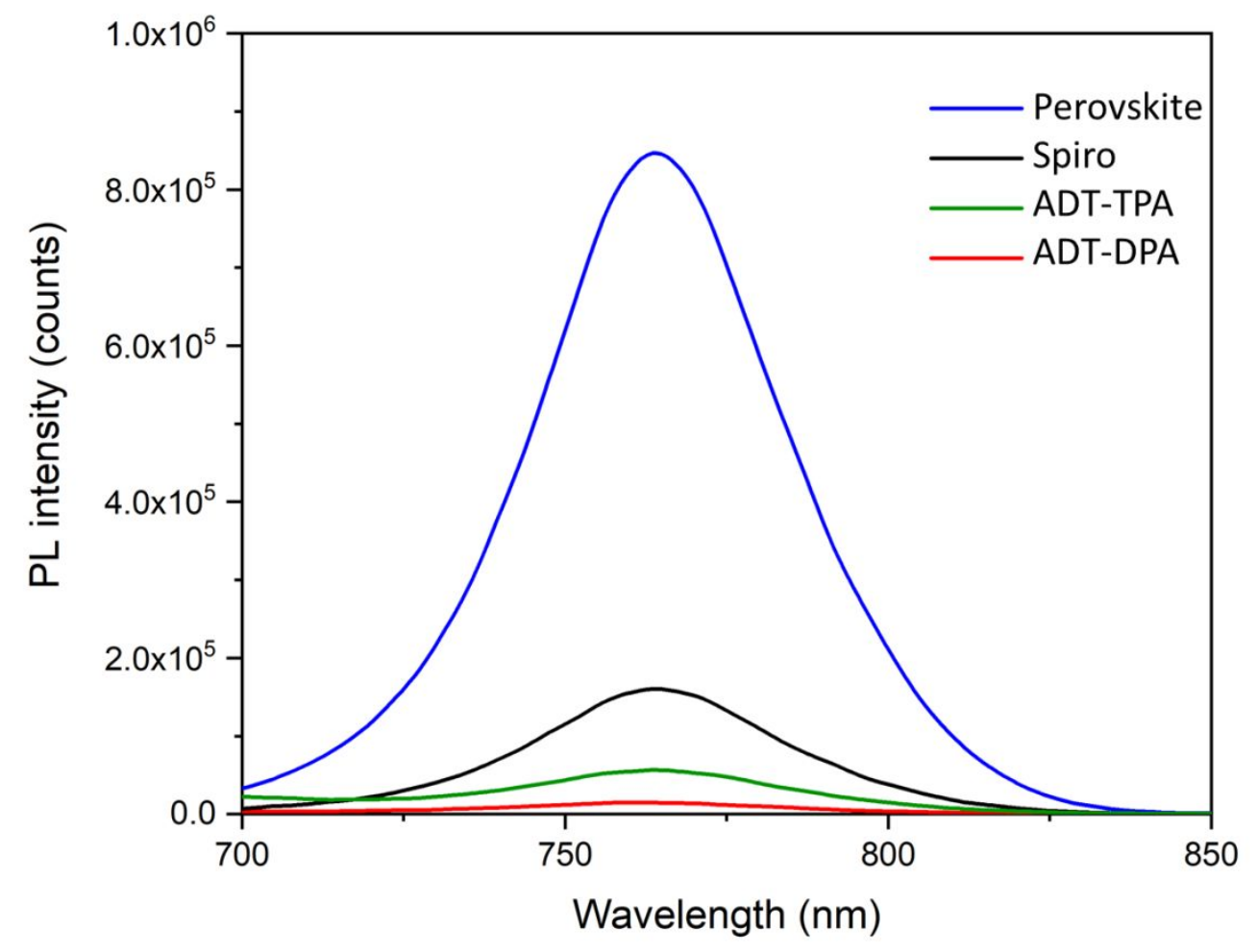

Figure S10. Photoluminescence spectra (excitation at $600 \mathrm{~nm}$ ) of pristine perovskite (PVK1), and of spiro-OMeTAD, ADT-TPA and ADT-DPA interfaced with PVK1. 

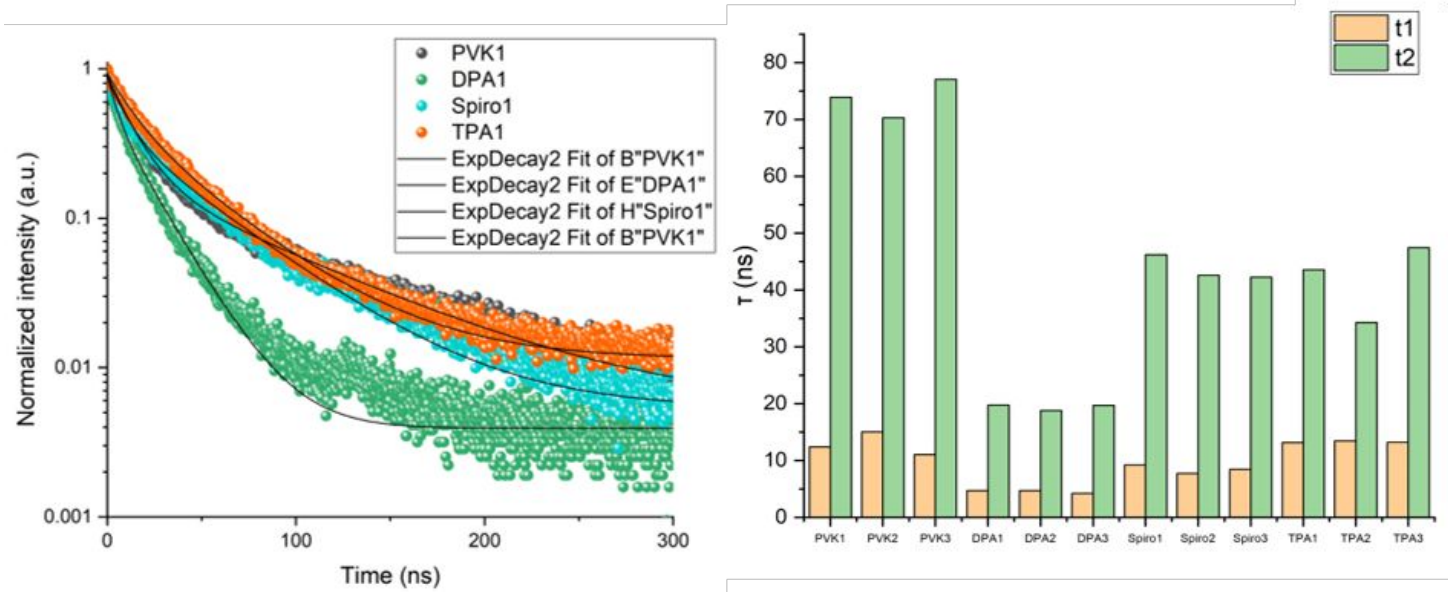

Figure S11. PL decay (left) and histograms (right) of $\mathrm{t} 1$ and $\mathrm{t} 2$ for pristine perovskite (PVK1), spiro-OMeTAD, ADT-TPA (TPA1) and ADT-DPA (DPA-1). A double exponential decay for the fitting was employed: $y=y 0+A 1^{*} \exp (-(x-x 0) / t 1)+A 2^{*} \exp (-(x-x 0) / t 2)$.

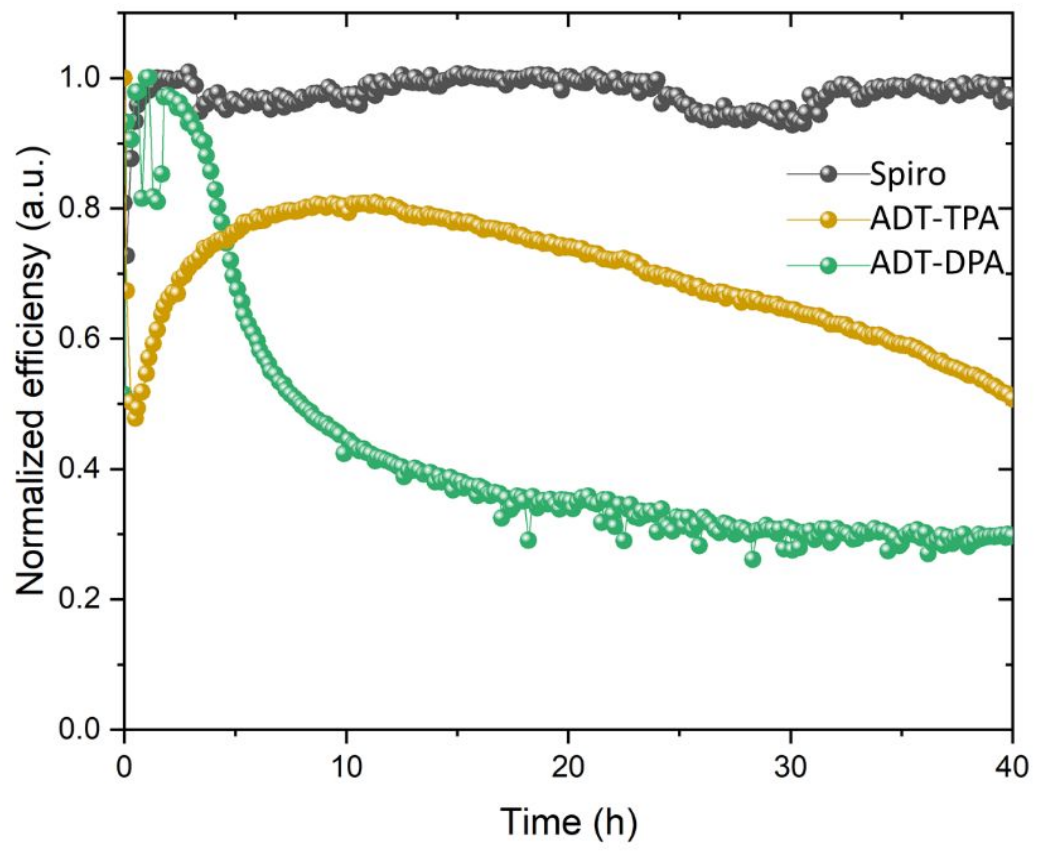

Figure S12. Normalized efficiency vs. time for perovskites solar cells with ADT-TPA, ADT-DPA and Spiro-OMeTAD under 1 sun illumination at $25^{\circ} \mathrm{C}$. 


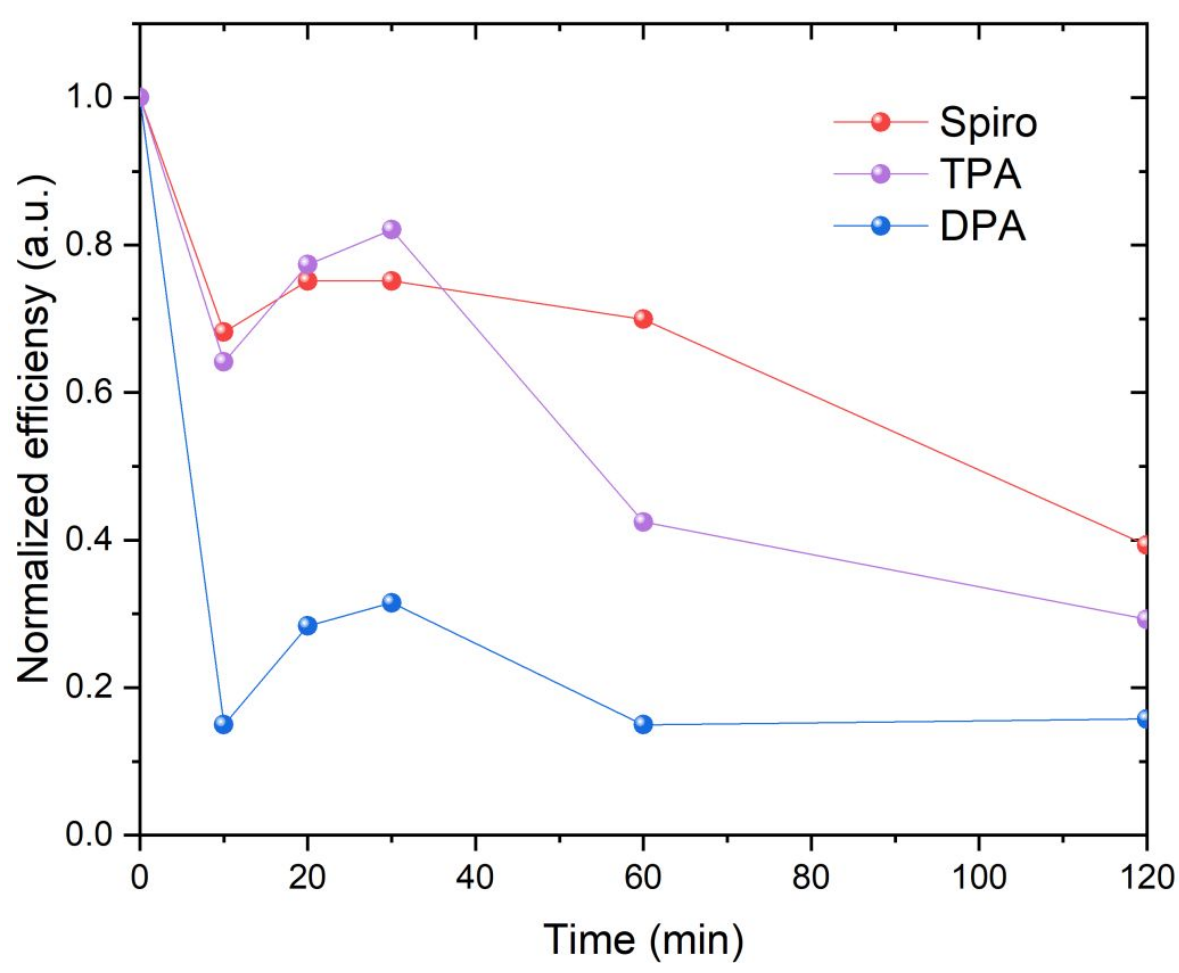

Figure S13. Normalized efficiency vs. time at $85^{\circ} \mathrm{C}(\mathrm{RH} 20 \%$ in air) for perovskites solar cells with ADT-TPA, ADT-DPA and Spiro-OMeTAD.

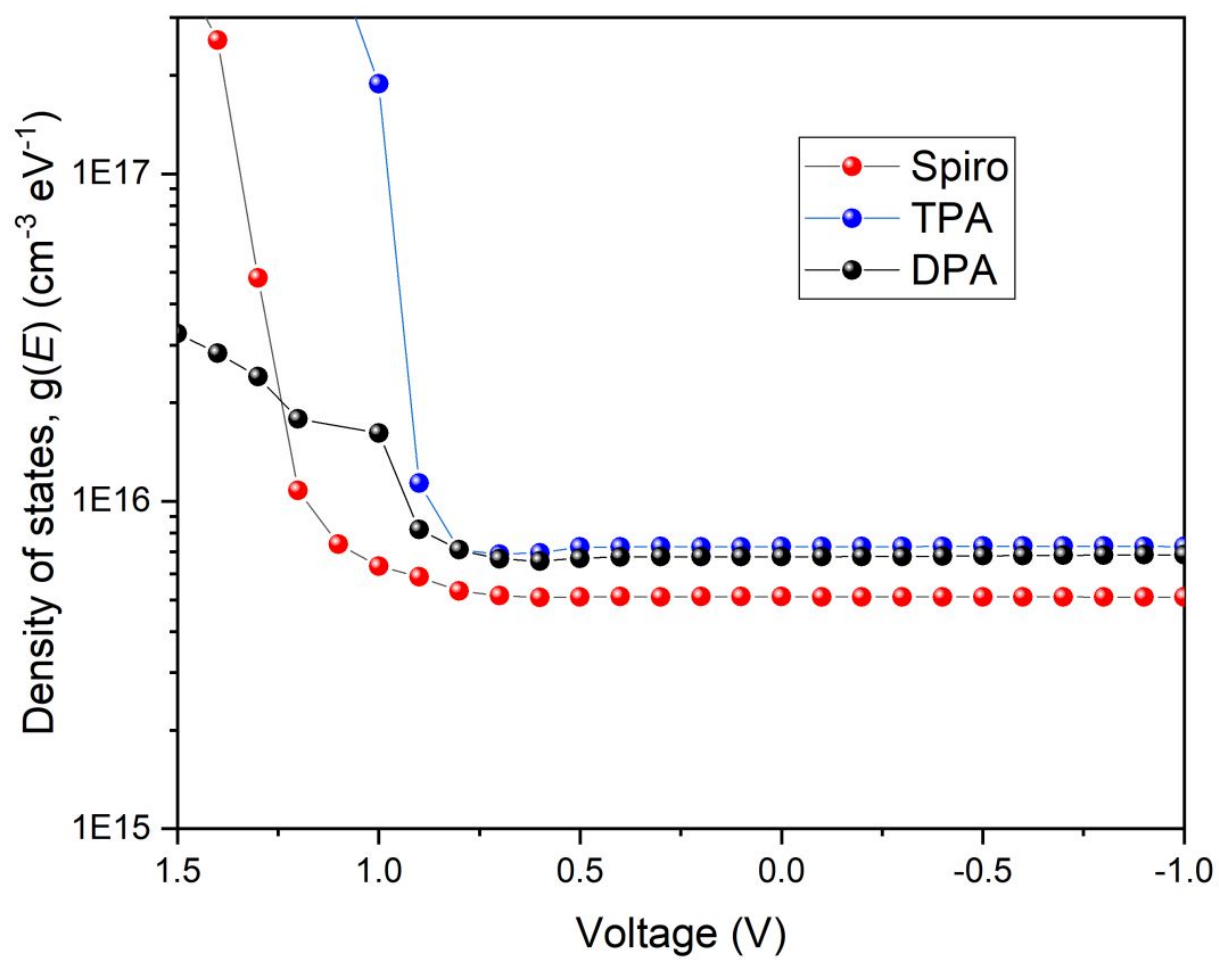

Figure S14. Density of states vs. voltage curves for ADT-TPA, ADT-TPA and spiro-OMeTAD. 


\section{6. ${ }^{1} \mathrm{H} N M R,{ }^{13} \mathrm{C}$ NMR and HMRS spectra}
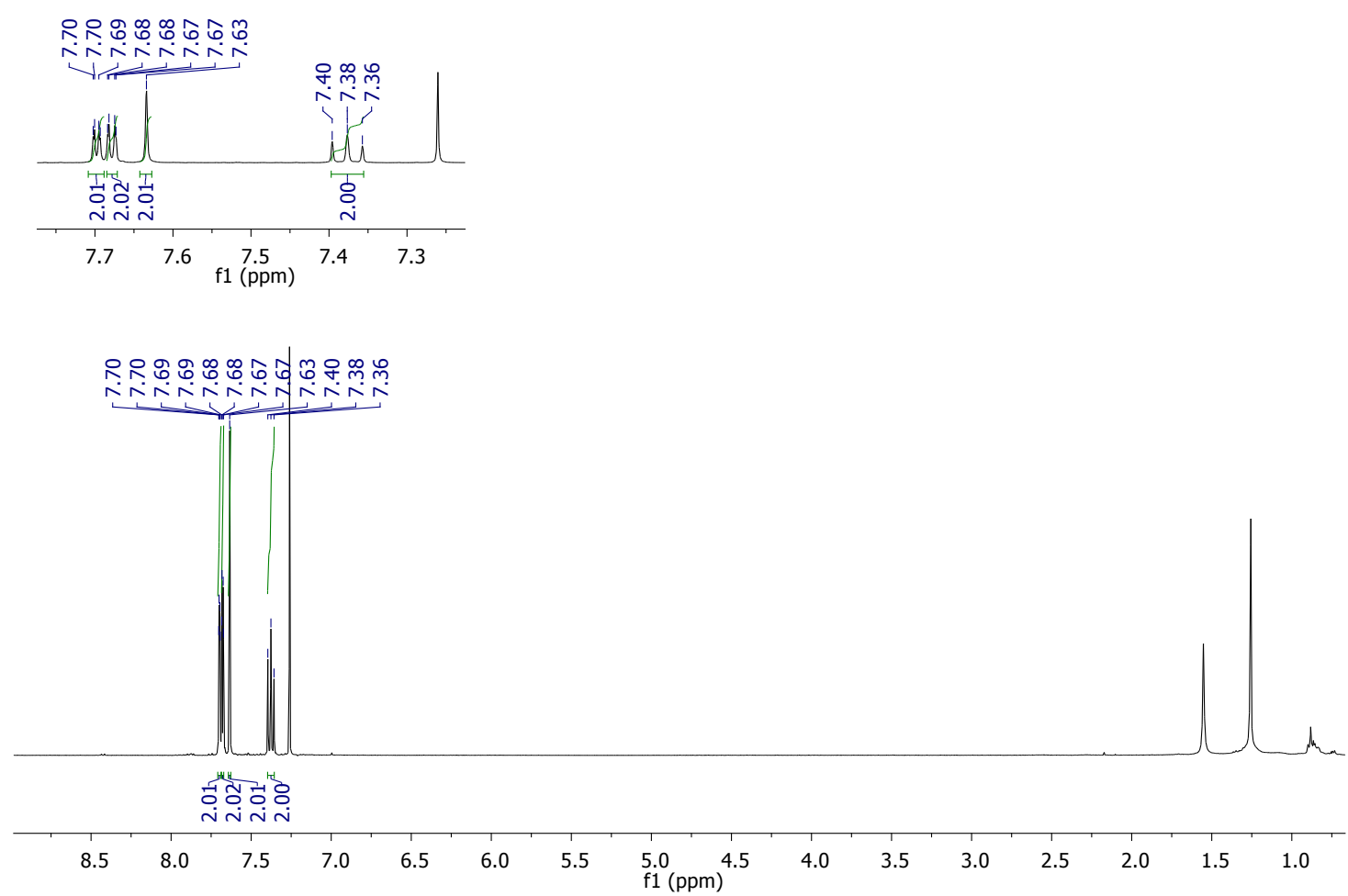

Figure S15. ${ }^{1} \mathrm{H}$ NMR $\left(400 \mathrm{MHz}, \mathrm{CDCl}_{3}, 298 \mathrm{~K}\right)$ of compound 2.
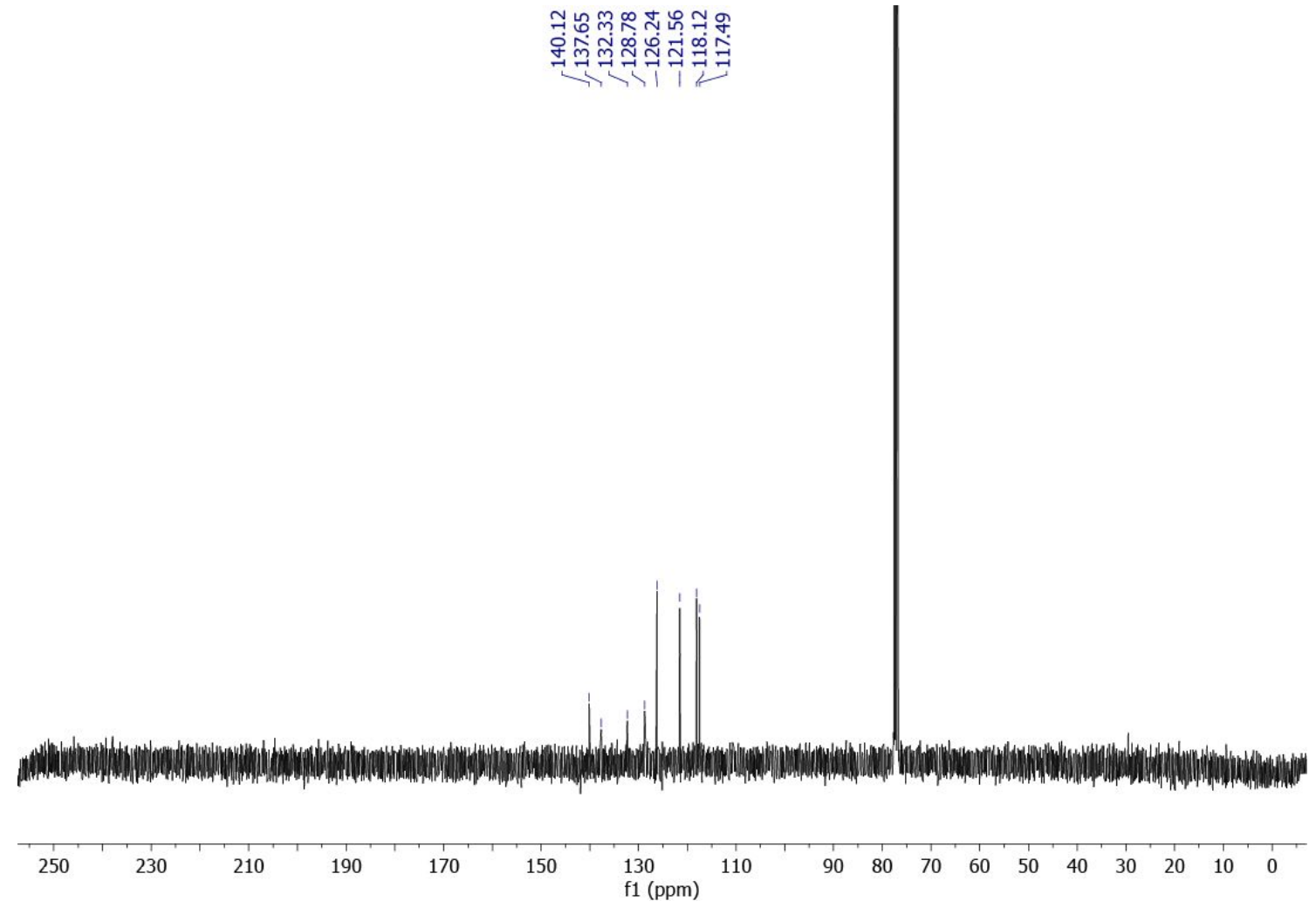

Figure S16. ${ }^{13} \mathrm{C}$ NMR $\left(176 \mathrm{MHz}, \mathrm{CDCl}_{3}, 298 \mathrm{~K}\right)$ of compound 2. 


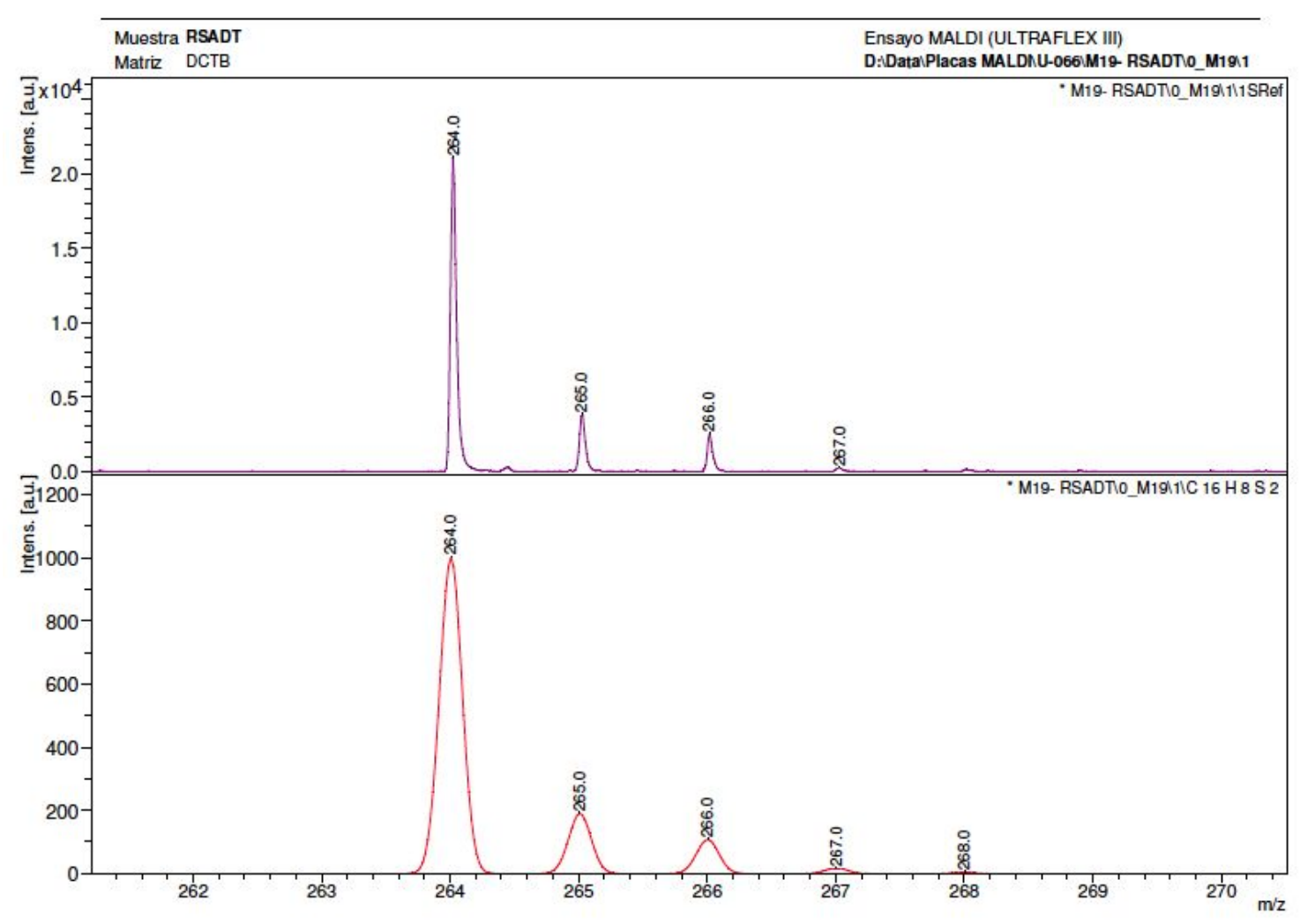

Figure S17. MALDI-TOF mass spectrum of 2.
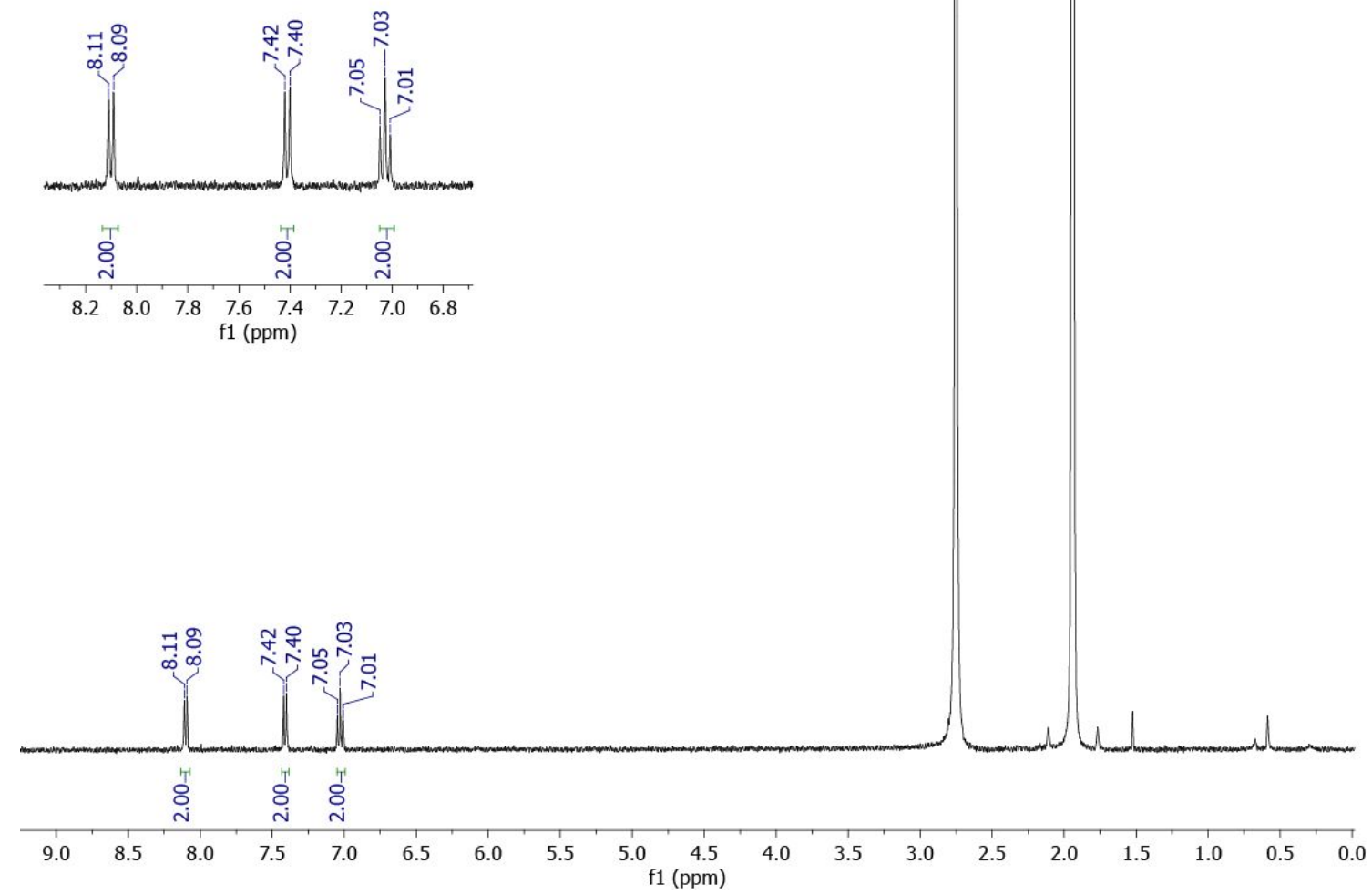

Figure S18. ${ }^{1} \mathrm{H}$ NMR (400 MHz, DMSO-d6, $298 \mathrm{~K}$ ) of compound 3. 


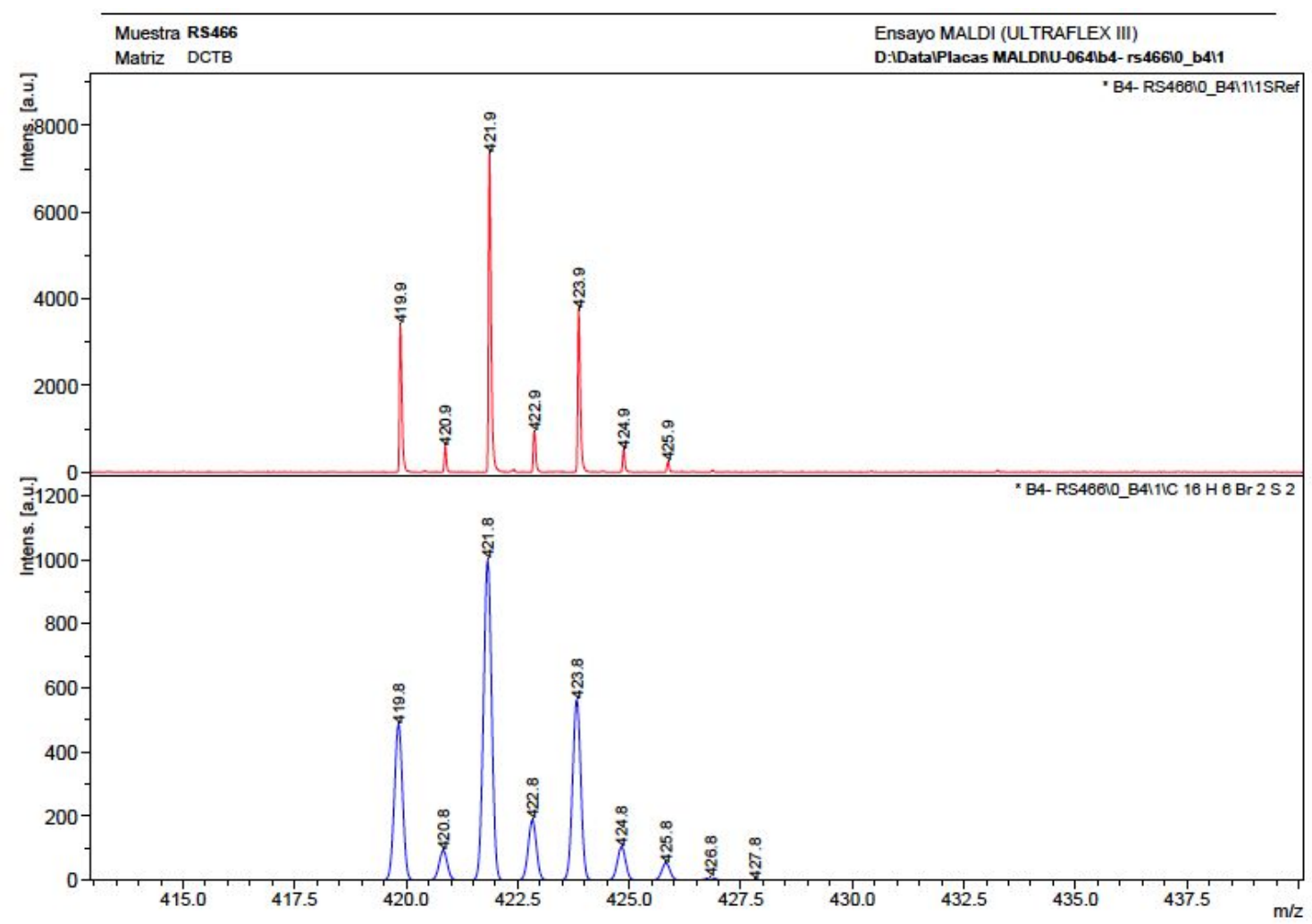

Figure S19. MALDI-TOF mass spectrum of 3.

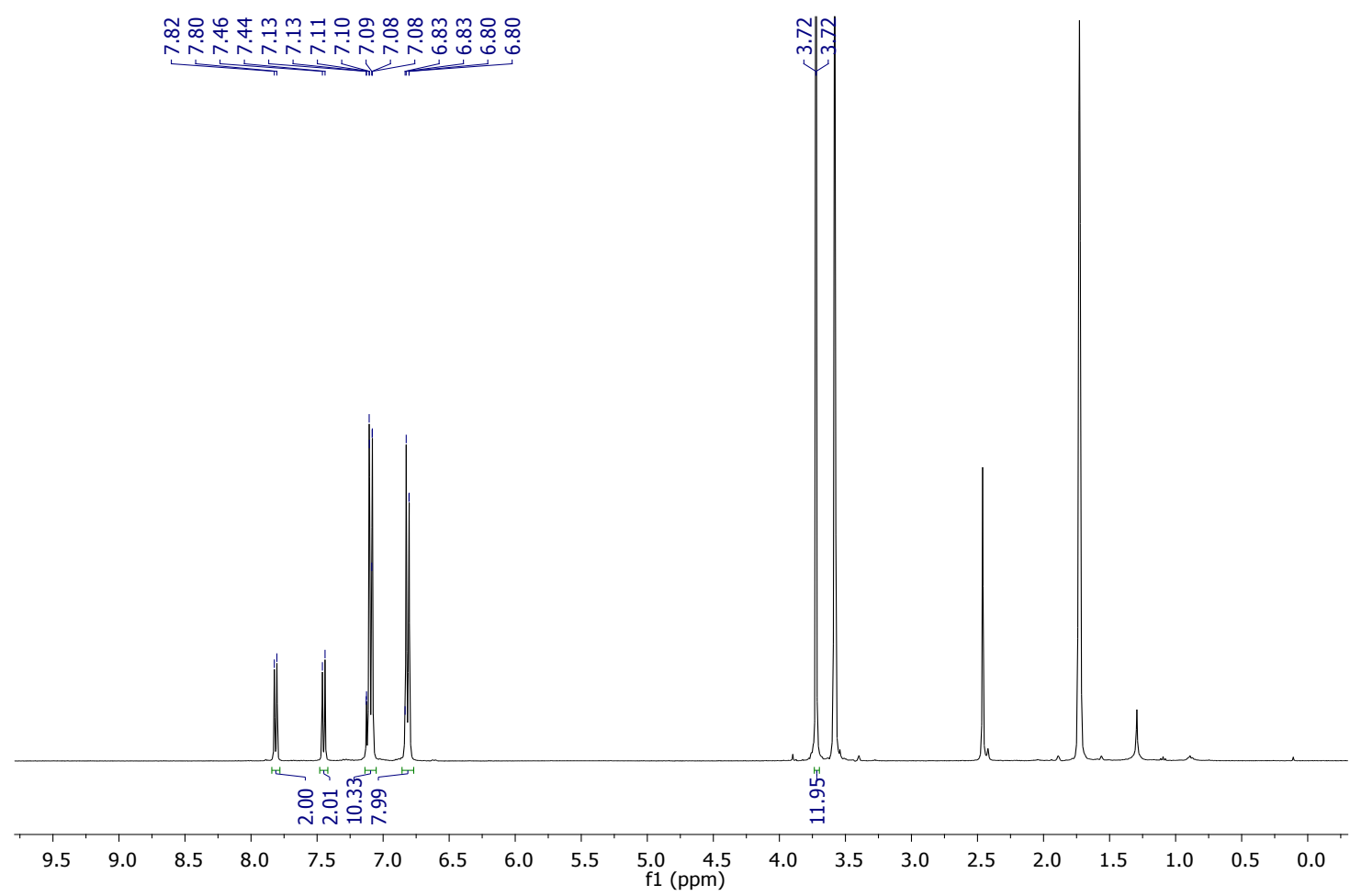

Figure S20. ${ }^{1} \mathrm{H}$ NMR $\left(400 \mathrm{MHz}, \mathrm{THF}-\mathrm{d}^{8}, 298 \mathrm{~K}\right)$ of ADT-DPA. 


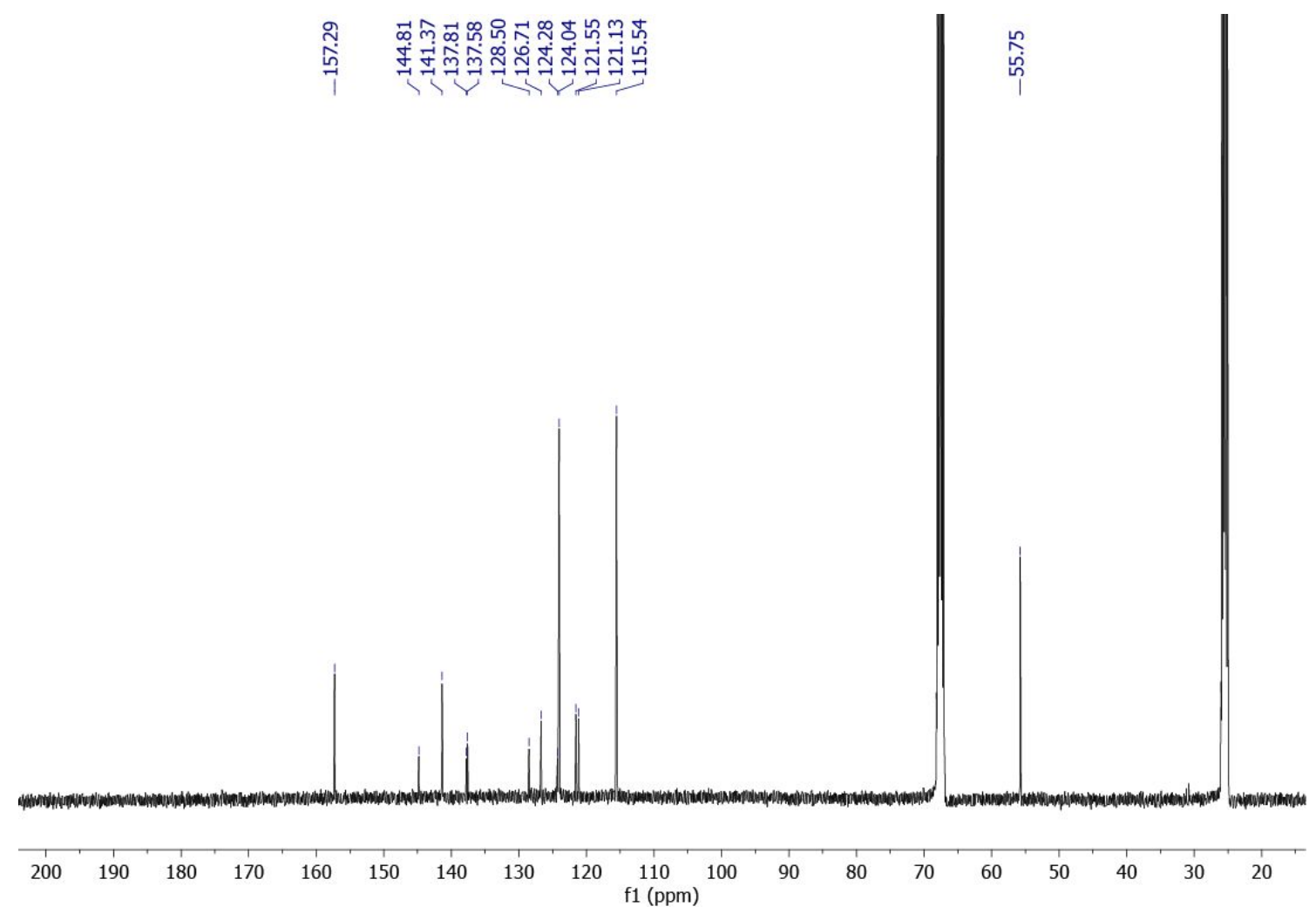

Figure S21. ${ }^{13} \mathrm{C}$ NMR (176 MHz, THF-d 8 , $298 \mathrm{~K}$ ) of ADT-DPA.

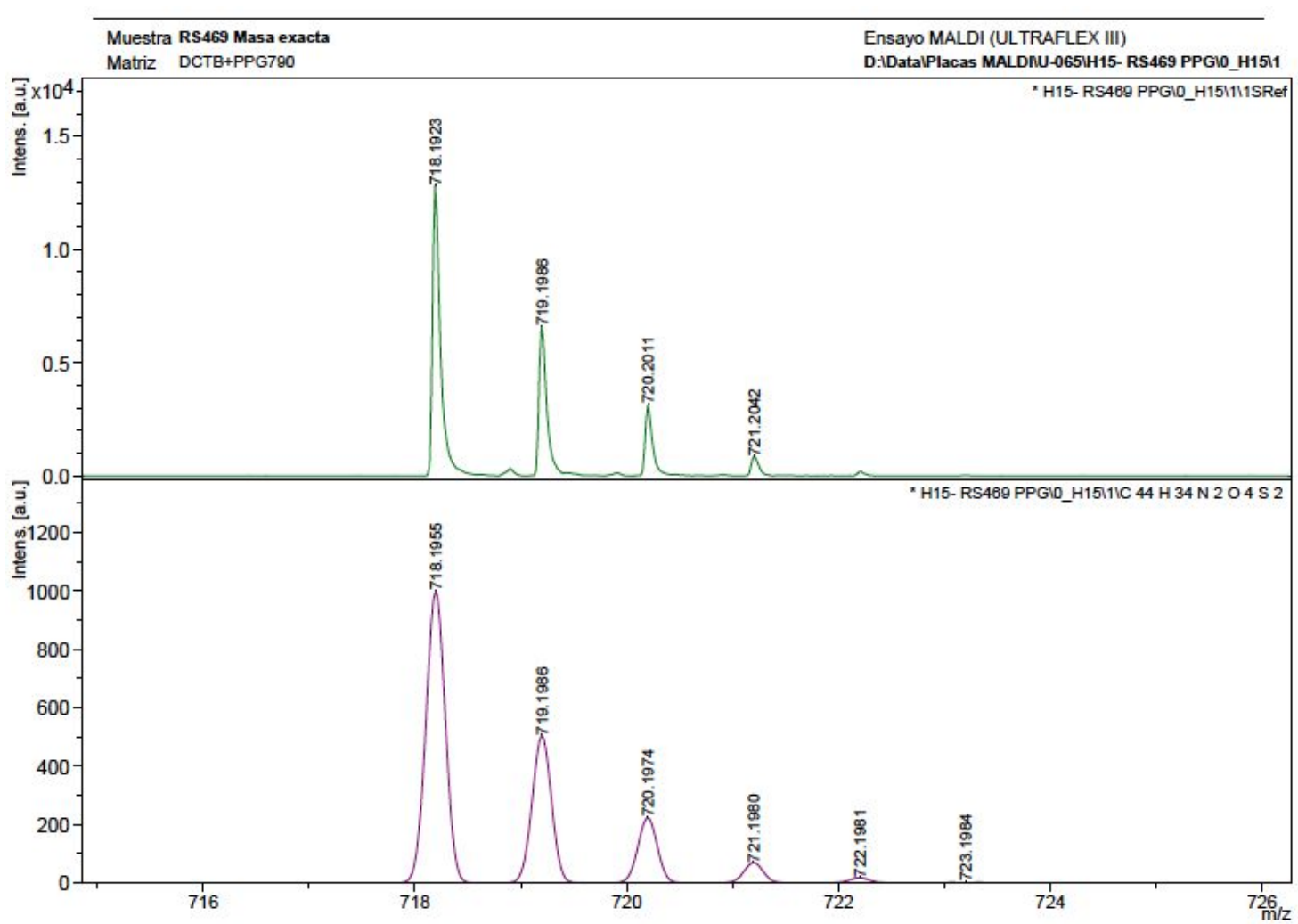

Figure S22. MALDI-TOF mass spectrum of ADT-DPA. 


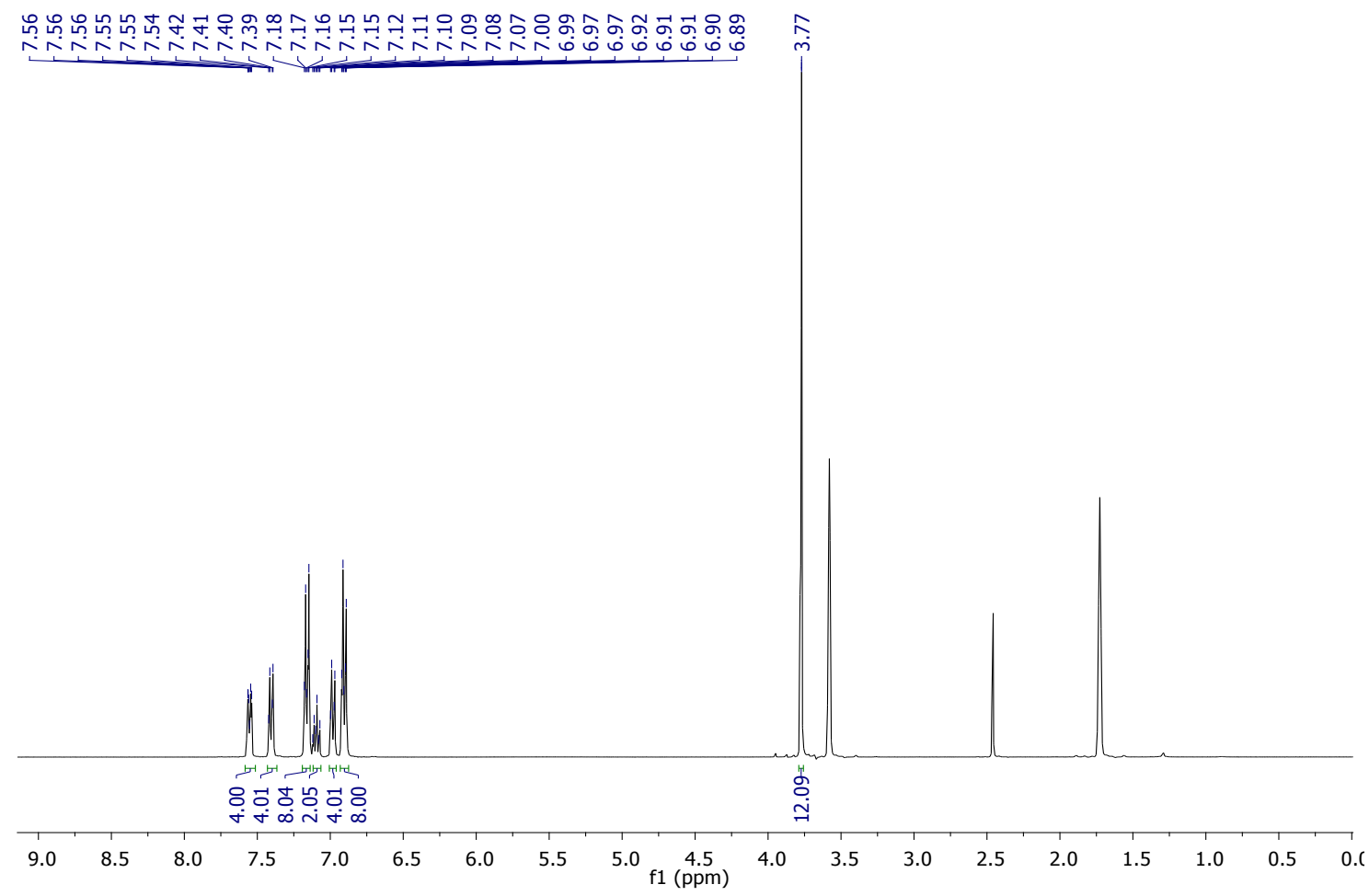

Figure S23. ${ }^{1} \mathrm{H}$ NMR $\left(400 \mathrm{MHz}, \mathrm{THF}-\mathrm{d}^{8}, 298 \mathrm{~K}\right)$ of ADT-TPA.

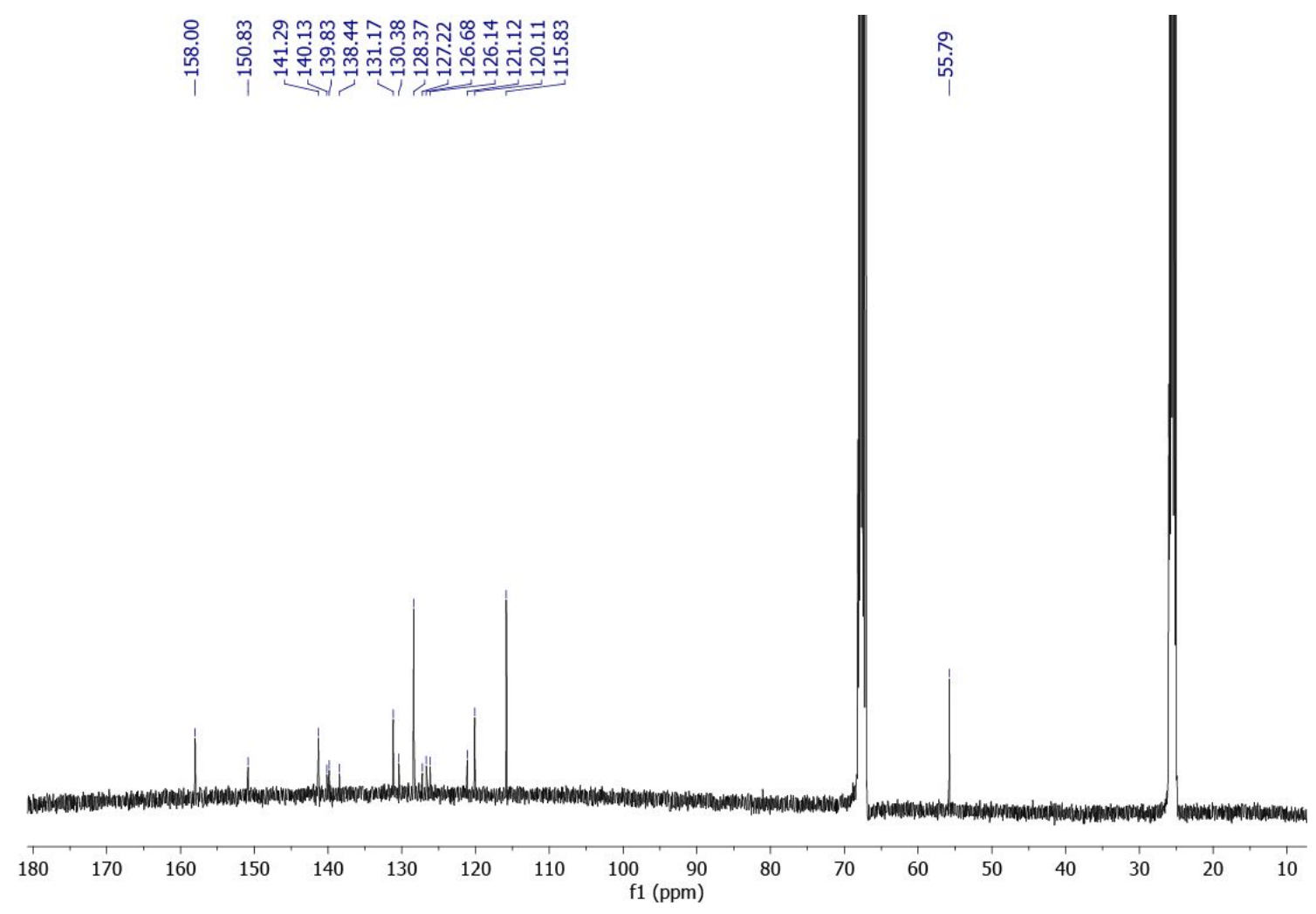

Figure S24. ${ }^{13} \mathrm{C}$ NMR (176 MHz, THF-d $\left.{ }^{8}, 298 \mathrm{~K}\right)$ of ADT-TPA. 


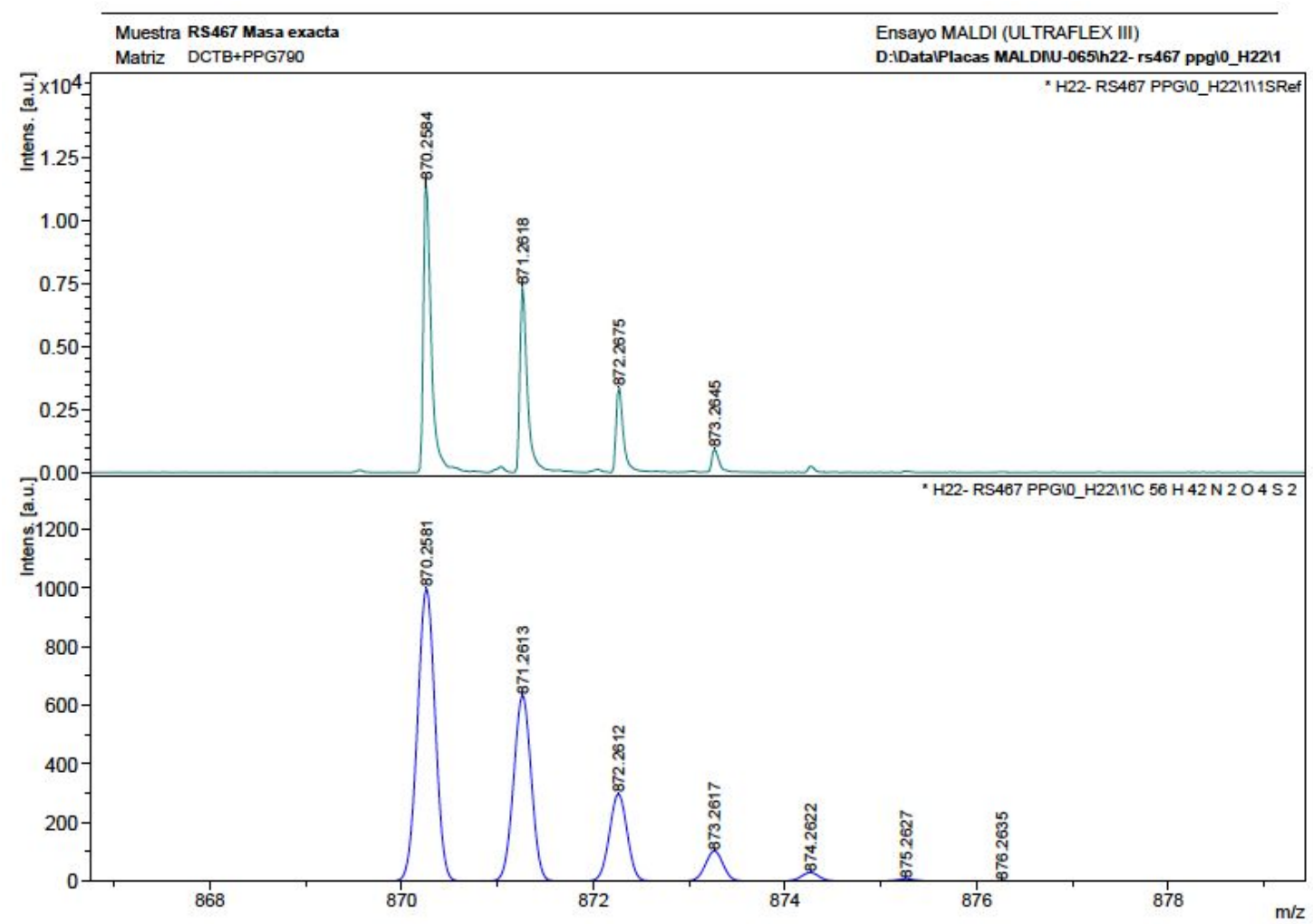

Figure S25. MALDI-TOF mass spectrum of ADT-TPA.

\section{References}

(1) Hill, L. L.; Moore, L. R.; Huang, R.; Craciun, R.; Vincent, A. J.; Dixon, D. A.; Chou, J.; Woltermann, C. J.; Shaughnessy, K. H. Bulky Alkylphosphines with Neopentyl Substituents as Ligands in the Amination of Aryl Bromides and Chlorides. J. Org. Chem. 2006, 71, 5117-5125.

(2) Rakstys, K.; Abate, A.; Dar, M. I.; Gao, P.; Jankauskas, V.; Jacopin, G.; Kamarauskas, E.; Kazim, S.; Ahmad, S.; Grätzel, M.; Nazeeruddin, M. K. TriazatruxeneBased Hole Transporting Materials for Highly Efficient Perovskite Solar Cells. J. Am. Chem. Soc. 2015, 137, 16172-16178.

(3) Gaussian16, Revision A.03, Frisch, M. J.; Trucks, G. W.; Schlegel, H. B.; Scuseria, G. E.; Robb, M. A.; Cheeseman, J. R.; Scalmani, G.; Barone, V.; Petersson, G. A.; Nakatsuji, H.; Li, X.; Caricato, M.; Marenich, A. V.; Bloino, J.; Janesko, B. G.; Gomperts, R.; Mennucci, B.; Hratchian, H. P.; Ortiz, J. V.; Izmaylov, A. F.; Sonnenberg, J. L.; Williams-Young, D.; Ding, F.; Lipparini, F.; Egidi, F.; Goings, J.; Peng, B.; Petrone, A.; Henderson, T.; Ranasinghe, D.; Zakrzewski, V. G.; Gao, J.; Rega, N.; Zheng, G.; Liang, W.; Hada, M.; Ehara, M.; Toyota, K.; Fukuda, R.; Hasegawa, J.; Ishida, M.; Nakajima, 
T.; Honda, Y.; Kitao, O.; Nakai, H.; Vreven, T.; Throssell, K.; Montgomery Jr., J. A.; Peralta, J. E.; Ogliaro, F.; Bearpark, M. J.; Heyd, J. J.; Brothers, E. N.; Kudin, K. N.; Staroverov, V. N.; Keith, T. A.; Kobayashi, R.; Normand, J.; Raghavachari, K.; Rendell, A. P.; Burant, J. C.; lyengar, S. S.; Tomasi, J.; Cossi, M.; Millam, J. M.; Klene, M.; Adamo, C.; Cammi, R.; Ochterski, J. W.; Martin, R. L.; Morokuma, K.; Farkas, O.; Foresman, J. B.; Fox, D. J. Gaussian Inc. Wallingford CT, 2016.

(4) a) Lee, C.; Yang, W.; Parr, R. G. Development of the Colle-Salvetti correlation-energy formula into a functional of the electron density. Phys. Rev. B 1988, 37, 785-789; b) Becke, A. D. Density-Functional Thermochemistry. III. The Role of Exact Exchange. J. Chem. Phys. 1993, 98, 5648-5652.

(5) Francl, M. M.; Pietro, W. J.; Hehre, W. J.; Binkley, J. S.; Gordon, M. S.; Defrees, D. J.; Pople, J. A. Self-Consistent Molecular Orbital Methods. XXIII. A Polarization-Type Basis Set for Second-Row Elements. J. Chem. Phys. 1982, 77, 3654-3665.

(6) a) Tomasi, J.; Persico, M. Molecular Interactions in Solution: An Overview of Methods Based on Continuous Distributions of the Solvent. Chem. Rev. 1994, 94, 2027-2094; b) Tomasi, J.; Mennucci, B.; Cammi, R. Quantum Mechanical Continuum Solvation Models. Chem. Rev. 2005, 105, 2999-3093; c) Cramer, C. S.; Truhlar, D. G.; in: Solvent Effects and Chemical Reactivity (Eds.: O. Tapia, J. Bertrán), Kluwer, Dordrecht, The Netherlands, 1996, p. 1-80.

(7) a) Casida, M. E.; Jamorski, C.; Casida, K. C.; Salahub, D. R. Molecular Excitation Energies to High-Lying Bound States from Time-Dependent DensityFunctional Response Theory: Characterization and Correction of the TimeDependent Local Density Approximation Ionization Threshold. J. Chem. Phys. 1998, 108, 4439-4449; b) Jamorski, C.; Casida, M. E.; Salahub, D. R. Dynamic Polarizabilities and Excitation Spectra from a Molecular Implementation of Time-Dependent Density-Functional Response Theory: $\mathrm{N}_{2}$ as a Case Study. J. Chem. Phys. 1996, 104, 5134-5147; c) Petersilka, M.; Gossmann, U. J.; Gross, E. K. U. Excitation Energies from Time-Dependent Density-Functional Theory. Phys. Rev. Lett. 1996, 76, 1212-1215.

(8) From http://www.chemcraftprog.com 